\title{
'Pākēhā Librarianship at the Interface' Being an ally in Māori student success through teaching and learning information literacies
}

By

Alexander JR Ritchie

Submitted to the School of Information Management,

Victoria University of Wellington

in partial fulfilment of the requirements for the degree of

Master of Information Studies

\section{June 2013}




\section{Abstract}

Research problem: Emerging from significant bicultural change within Aotearoa New Zealand libraries in the past 25 years, this research examines and attempts to implement an relationshipbased, culturally relevant approach to teaching and learning information literacy in an academic library, building on an approach outline by Roy, Lilley and Luehrsen (2011).

Methodology: This exploratory study employed an action research methodology and was conducted within the Division of Sciences at Otago University. It sought to consult Māori staff and senior postgraduates, and then develop a teaching intervention for undergraduate Māori science students, then evaluate it with them. Weaving a research framework incorporating Kaupapa Māori theory, Research at the Interface, \& Pākēhā as Ally of Tino Rangatiratanga, it was planned in three stages; observe \& plan; act; and evaluate.

Results: Only the initial stage was able to be carried out due to time constraints.Preliminary findings cover six main themes addressing student support and information literacy teaching with undergraduate Māori science students, including: the challenges of 'crossing the library threshold' and sustaining student engagement, developing ongoing relationships of integrity and reciprocity in the library, holistic student development and recognising student diversity, and finally culturally-relevant teaching for effective learning. Reflections on researching as pākēhā with Māori staff and students at in university context, and noted the importance of timing and place in supporting Māori students, and the need for relationships of integrity and mutual respect enabled by ongoing communication.

Implications: Academic libraries can improve support for Māori student success at University, and pākehā librarians must take a role supporting this work. Culturally-relevant models of teaching and learning information literacy, combined with attention to developing relationships of trust, reciprocity and mutual respect, may improve Māori student success and support development of both library staff and relevant, effective library services. Future research could examine the use of storytelling and song in 'interface' information literacies teaching and learning as well as investigating mixed methods evaluation of this approach, and explore cross-cultural rituals of encounter in the library.

Keywords: cultural interface, tino rangatiratanga, ally, pākehā, māori, academic libraries, information literacies, pedagogy, Aotearoa New Zealand. 


\section{Acknowledgements}

To everyone who participated in this research, thank you for you conversation, your sharing, and your insights.

To my supporter and colleague, Jeanette, thank you for walking alongside me in this process, for advising and supporting me, for staying in conversation, and for championing this project.

To whaea Pearl and staff at the Māori Centre, thank you for your willingness to engage, your support, and your questions. I look forward to continuing to work in support of your mahi.

To Tia, many thanks, e hoa, for your clear sight, sage advice and guidance.

To Hiria and Stephen in Division of Sciences, thanks for your support, and for ongoing collaboration.

To my colleagues at the Science Library, many thanks for your encouragement, your listening ears hunched over commiseratory cups of tea.

To Sydney Shep, my outstanding supervisor, for you engagement with this project, your enthusiasm, your insightful extension of my learning, your empathy, and your ongoing availability, thank you. Thank you!

Finally, to my family. Howard who got me started on the journey, Rob who has been walking the path for many years, and foremost, Justine and Story, hearts of my heart, whose life has been diverted in the last four and a half years while I got to this point. For your unconditional love, support and insightful questioning, your cupcakes and your angry bird star wars.

Ngā mihi nunui ki a koutou.

Mauri Ora!

Alexander Ritchie

20 June 2013 


\section{Table of Contents}

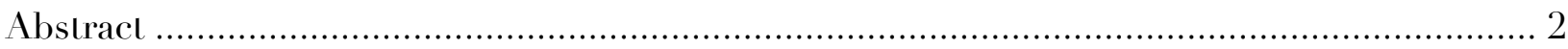

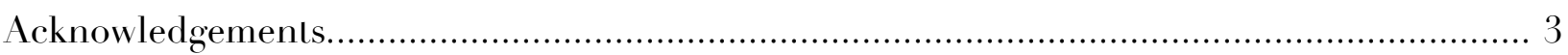

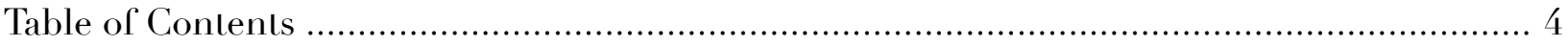

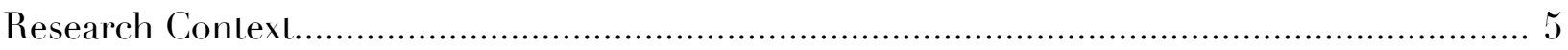

Support for Māori Students at University of Otago Library ........................................... 6

An Indigenous Approach to Teaching and Learning Information Literacy .......................

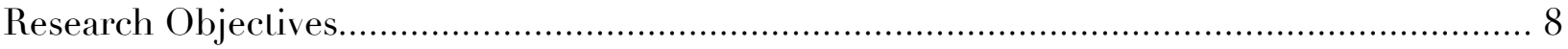

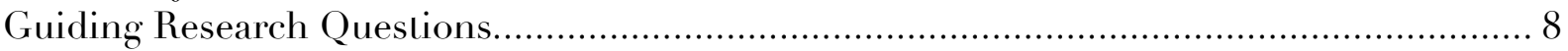

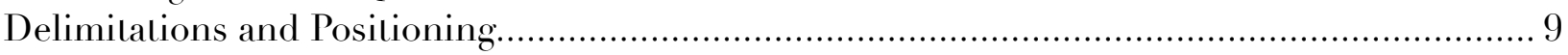

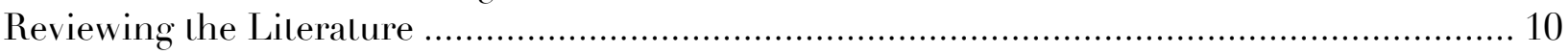

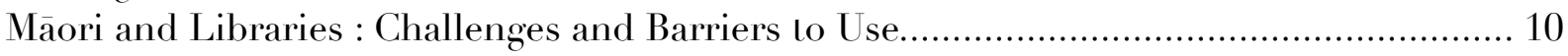

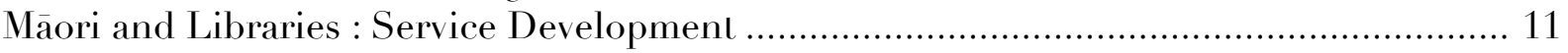

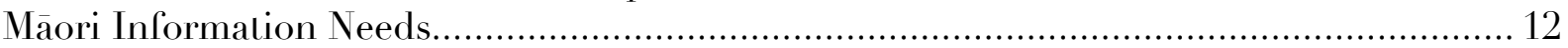

Māori Pedagogies :Teaching and Learning with Māori Students....................................13

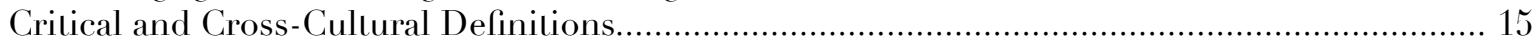

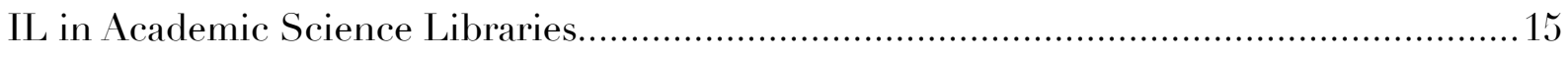

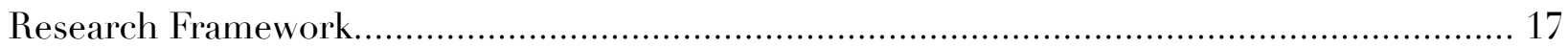

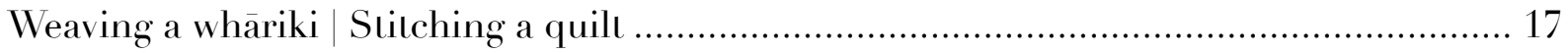

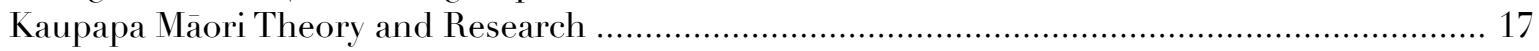

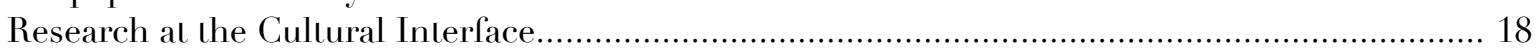

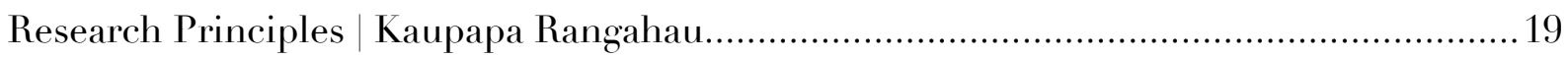

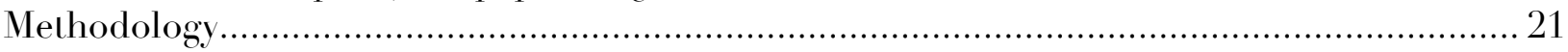

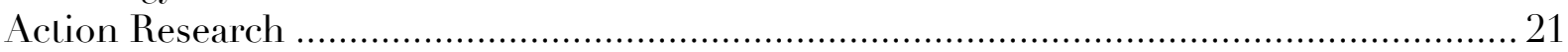

Investigating Teaching and Learning Information Literacy with Māori Science Students ..21

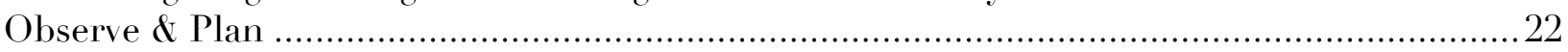

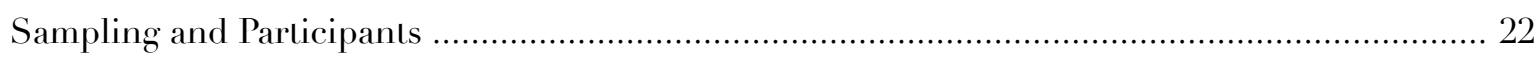

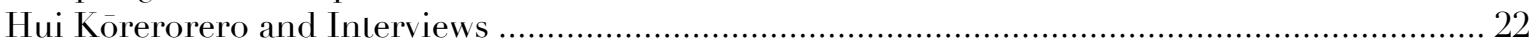

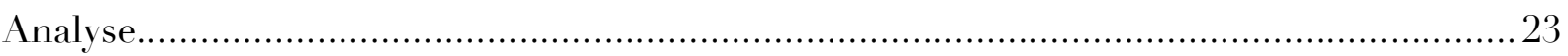

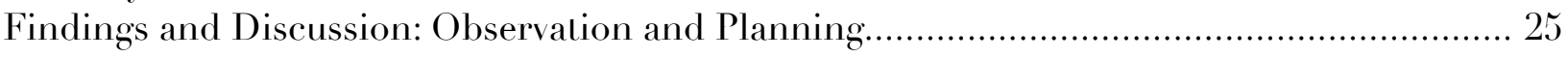

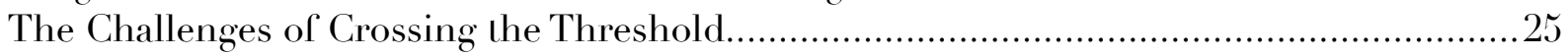

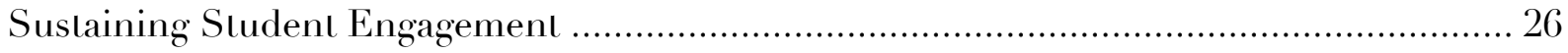

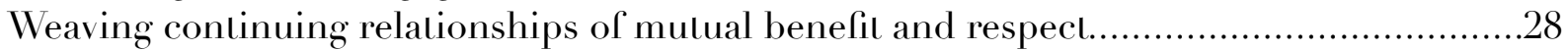

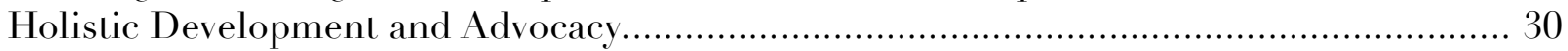

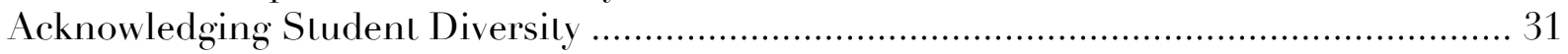

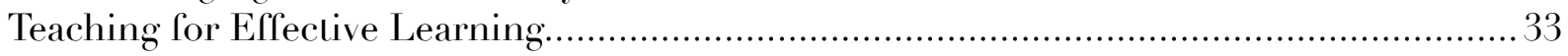

Te Library Stuff: greetings across the threshold.................................................... 34

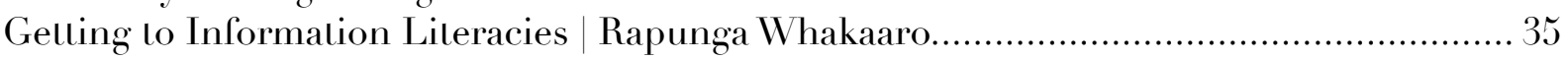

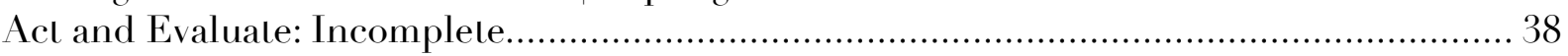

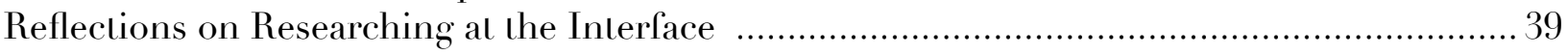

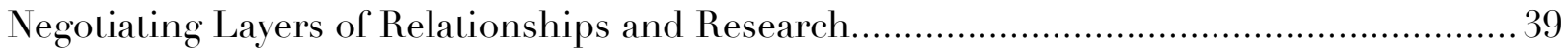

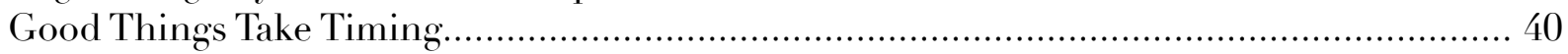

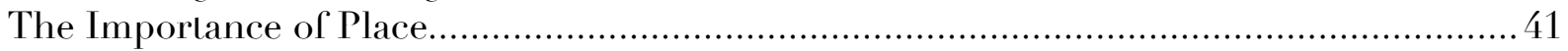

Conversations and Cross-cultural Communication ......................................................... 42

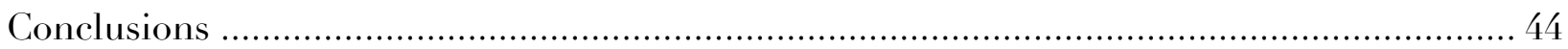

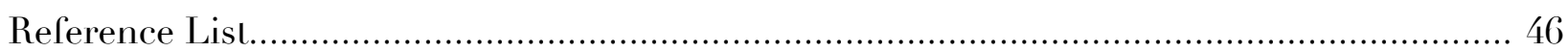




\section{Research Context}

This research emerges from my enduring commitment as a pākēhā man to understanding the ongoing consequences of colonisation for all who live in Aotearoa New Zealand, whether Māori or Pākēhā, tangata whenua or tau iwi. This project is concerned with colonisation, how it continues to shape all libraries in Aotearoa, and some ways in which pākēhā and tau iwi librarians can address that.

It begins from the acknowledgement of Māori as the indigenous people of Aotearoa New Zealand, and recognises that since the signing of the country's founding document, the Treaty of Waitangi in 1840, tangata whenua have survived sustained state policies of cultural annihilation by the Crown. As outlined by Māori and Pākēhā scholars such as Ranginui Walker (1990), Linda Tuhiwai Smith (2012), Judith Binney (2009), these policies have involved theft and confiscation of land and natural resources, suppression of language, spiritual belief and cultural practice, and other treatment in breach of the Treaty of Waitangi.

The final decades of the twentieth century witnessed a cultural renaissance among whānau, hapū and iwi Māori, which in turn was supported by and gave rise to political and legal challenges by Māori to the state's policies toward them. Emerging from the social and political ferment of the 1980s, processes were initiated to acknowledge and redress wrongs done to Māori by the state not only through Treaty settlements - involving apologies and financial redress - but also through official policies of biculturalism, which began to acknowledge the place of Māori as indigenous people of Aotearoa.

Many scholars have described the inadequacies of the state-provided compulsory education system for Māori (For example Bishop, 2008; Milne, 2009; Pere, 1982). Kaupapa Māori initiatives such as kōhanga reo | early childhood Māori-medium centres and Māori-led early childhood curriculum development - Te Whāriki - in the 1980s and 1990s have been followed by state compulsory education strategies - such as Ka Hikitia (Ministry of Education, 2008) - and initiatives by Iwi Māori - such as Te Rūnanga o Ngāi Tahu (2006), and the ART confederation establishing the Wānanga o Raukawa - in higher education. Universities too have begun to develop policies and strategic frameworks which recognise and support Māori educational and cultural aspirations as Māori within the University system (see for example University of Auckland, 2013; University of Otago, 2007).

Alongside this process in educational institutions, is a process of challenge and change within libraries across Aotearoa. In the past quarter century, libraries and librarians have sought to hear 
the challenges put by whānau, hapū and iwi Māori, to understand and meet the needs of Māori library users. Following the founding of Te Rōpū Whakahau as a network in 1992 then an independent body in 1995 , this process of engagement is most notably attested to by the Te Ara Tika project (MacDonald, 1993; Simpson, 2005; Szekely, 1997). The continued development and evaluation of library services for Māori, and the deeper work to engage in full partnership with Māori is an ongoing process of change in philosophy, policy and practice that continues slowly to unfold (Auckland City Libraries, 1995; Christchurch City Libraries, 2008; National Library of New Zealand, 2006; Peters, 2006).

As part of this process, academic libraries are also seeking to support Māori educational achievement through policy (see for example University of Otago Library, 2008) and practical initiatives (Lilley \& Field, 2005; Tautolo, 2012).

\section{Support for Māori Students at University of Otago Library}

At the University of Otago, two FTE Māori Resources Librarian roles were created, and a Māori collection and space, Te Aka a Tawhaki, were established in 2003. In 2006, Te Haumi, the Library's Māori Services support group, was formed involving both Māori and Pākēhā staff. In 2008, the Māori Resources Librarian and Te Haumi released a Māori Services Strategy (University of Otago Library, 2008) From 2009, the Māori Resources Librarian role stood vacant for two and a half years, following the departure of the person holding that role. A FTE Māori Resources Library Assistant remained and continued to maintain the Te Aka collection and space. Changes in the library meant that this role was later changed. In 2012, the Maori librarian role was redesigned and renamed Māori Resources Portfolio Librarian, with a more strategic focus and oversight of developing services for Māori in the Library. The recently completed internal library Te Aka Project report produced by that librarian, sought to engage with Māori student perspectives on the library (Wikaira-Murray, 2012). It found among other things that Māori students seek and value meaningful, personal relationships with library staff to support their study and research, and that initial entry into the library as a new student can be challenging.

\section{An Indigenous Approach to Teaching and Learning Information Literacy}

Against that background, the research was specifically inspired by the approach to teaching and 
learning information literacy for Māori students and staff, developed by Dr Spencer Lilley and his colleagues at the Massey University Library (Roy et al., 2011). Designed in part in response to the high proportion of distance students enrolled in the University, this was part of a University wide strategy to develop services for Māori@Massey.

This is a culturally-specific framework that guides the development and delivery of library instruction, through development of ongoing relationships with Māori staff and the embedding of information literacy directly into courses with high Māori enrolment Its underlying principles and values are:

- Whakawhanaungatanga $\mid$ building connections

- Mana $\mid$ enhancing pride/prestige

- Tautokotanga | ensuring support mechanisms

- Manaakitanga $\mid$ creating a welcoming environment

- Tau utuutu $\mid$ reciprocity of teaching and learning

This will be used as a foundation for engaging with staff and students in undertaking teaching and learning in this project.

It is through weaving together these multiple contexts - ongoing service development for Māori in education and in libraries, the ongoing service development for Māori students at the University of Otago Library, and an emerging relationship- and values-based approach to library teaching and learning with Māori - that the research objectives for this project emerged. They are outlined in the next section. 


\section{Research Objectives}

In the study, I sought to contribute to the improvement of library services for Māori students at the University of Otago by exploring and developing culturally-relevant information literacy teaching and learning for undergraduates in the Sciences.

At the commencement of the research, the primary objectives of the study were:

1. to understand the culture- and discipline-specific information skills needs of Māori students in a University context, and

2. to build on the relationship- and values-based information skills teaching approach outlined in Roy, Lilley \& Luehrsen (2011), and develop culturally relevant information literacy teaching \& learning approach for librarians at the University Otago to use with Māori students, and

3. to evaluate the effectiveness of that teaching and learning approach for students and academic staff.

As the project developed, this evolved to include:

4. to outline a process for pākēhā and tau iwi librarians to engage with Māori staff and students at the University appropriately and effectively,

5. to consider further developments of support for Māori students within the University of Otago Library.

\section{Guiding Research Questions}

Embarking on this research, my primary question was:

How does the approach to engaging with Mäori staff and students in the outlined by Roy, Lilley and Luehrsen (2011) contribute to the acquisition and retention of information literacy skills?

As the project evolved, other related questions emerged:

- What elements ought to form part of a information literacy skills session that is culturallyrelevant to Māori students?

- What factors contribute to the effectiveness of these elements and the approach as a whole? 
- What would constitute an appropriate and ethical $\mid$ tika framework and process for pākēhā and tau iwi librarians to support Māori student success from within an academic library?

\section{Delimitations and Positioning}

This study was focussed on undergraduate Māori students within the Division of Sciences at University of Otago. It also engaged with Māori staff within the same Division, and staff working in Māori student support services.

With primary responsibility for conducting this research, I am a pākēhā man with ongoing interest and commitment to being an ally for positive change for Māori in Aotearoa. My approach was informed by writings from Mulqueeny (2012), Jones (2012), Jones and Jenkins (2008), and Margaret $(2010)$.

Mulqueeny (2012) discusses the importance of acknowledging pākēhā privilege in the counselling process as a Pākehā man working with Māori youth, and lessons from powhiri in the structure of the counselling encounter. This was helpful in developing my perspective on the privileged position of the pākēhā librarian and invited consideration of the ways in which encounters in the library are structured. Jones (2012), and Jones and Jenkins (2008) write about the challenge for pākehā or non-indigenous researchers working in indigenous context or with indigenous participants. They suggest that paying attention to history, to power dynamics, and to the tensions within relationships between Pākēhā and Māori is vital. Margaret (2010) describes the role of ally for white settler peoples working to support indigenous peoples in struggles for autonomy and self-determination. This role will be further elaborated in the research framework.

I will now move to examine the relevant library and education literature. 


\section{Reviewing the Literature}

While the focus of this project is effective information literacy teaching and learning for Māori students, there is limited research available in this area. Consequently, this literature review commences by exploring the relationship between whānau, hapū and iwi Māori and libraries, canvassing barriers to library usage as well as policies and initiatives to overcome those barriers. It then touches on issues of Māori and indigenous information needs, and Māori educational approaches, before finally examining information literacy in library literature, both generally and within the sciences.

\section{Māori and Libraries: Challenges and Barriers to Use}

Despite commencing nearly two decades ago, the Te Ara Tika project (MacDonald, 1993; Simpson, 2005; Szekely, 1997) looms large on the landscape of research into Maori (non)use of libraries in Aotearoa. Emerging from a context of ongoing discussion within and without libraries in the 1980s and early 1990s about Māori access to and use of libraries (see Garraway \& Szekely, 1994; McRae, 1990), the first part consisted of Tui MacDonald's (1993) analysis of activities and issues around services for Māori from the perspective of the Library profession. In the second part Chris Szekely (1997) sought to ascertain Māori perspectives on public libraries and information needs. The third, undertaken by Sally Simpson (2005), explored the issues facing Māori around information seeking.

The second part of the project, Guiding Voices (Szekely, 1997) has been particularly influential, owing to its comprehensive documenting of Māori perspectives about libraries and information needs through numerous hui around Aotearoa. It noted a variety of challenges faced by Māori when seeking to use libraries. Among the many issues raised, Szekely identified six main themes, the top two of which were:

- issues of intellectual access to Māori resources and information literacy,

- the need to focus on young people,

Other issues relevant to this research were the diversity of Māori information needs, issues of cultural safety, the need for librarians to pay attention to Māori issues. This report made a number of recommendations about improving library catering for Māori.

Tuhou's Masters of Information Studies (MIS) research (2011) offers some contemporary nuances 
to the barriers faced by Māori in libraries. Focussing specifically on academic libraries, he notes that barriers for Māori students include: lack of cultural safety unfamiliarity or alienation from the library protocols, discomfort around expectations of silence; lack of confidence to engage with library staff.

He suggests that these barriers may be experienced to different extents by postgraduate and undergraduate students, due to their different length of time engaging with the library systems, and that while the barriers experienced by the students are similar to those experienced throughout the university system, these were more often experienced in the library context.

\section{Māori and Libraries : Service Development}

Much of the research undertaken in the last decade and a half that has examined issues of information access and library services for Māori take Guiding Voices as a point of departure. Researchers have explored barriers that might persist for Māori to their use of and engagement with public and academic libraries, and documented the initiatives to improve access and services for Māori (Lilley \& Field, 2005; Tamaira, 2007; Tautolo, 2012). Issues signalled or foreshadowed in Guiding Voices, such as: separate Māori collections, access to Māori materials, desire for Māori staff can be traced through this more recent research.

Lilley and Field (2005) outline the developments of a specific Māori support framework in a university library context, following the development of the whole institution Māori@Massey strategy at Massey University. The paper describes the recruitment of staff, development of Māori specific collections and information literacy programmes, as well as professional development of existing library staff.

Tautolo (2012) describes steps taken to support the equity issues and student retention rates at Auckland University's Tai Tokerau campus, describing the change of focus in the library, provision of a welcoming environment, information literacy classes, emphasising the importance of relationships, normalising the presence of Maori in the library, and actively offering support to Māori students in the library. Pukepuke and Dawe (in press) describe the process of embedding a librarian within a tutorial and peer support programme for undergraduate social work students. While the programme is not just supporting Māori students, it is structured according to Māori principles, and the article is the only literature identified that explores pākēhā or tau iwi librarians actively working with Māori staff to support students in tertiary context. 
An additional but nonetheless important part of service development is documented in policy and strategy documents such as Te Ara Ноu (Christchurch City Libraries, 2008) and Te Kaupapa Mahi Tahi (National Library of New Zealand, 2006, 2010) articulate strategies to engage Māori communities, develop collections, support existing staff and recruit more Māori staff into libraries. Several public libraries, notably Auckland (Auckland City Libraries, 1995, 2002) and Manukau City (Peters, 2006), have conducted and reported on customer surveys in the desire to evaluate and continue to develop their services for Māori.

A recent MIS research paper examining kaupapa Maōri implementation in public libraries across Aotearoa New Zealand by Hayes (2012), however, suggests that bicultural development may have stalled. Finding an inconsistent application of kaupapa Māori across various public libraries, Hayes finds that a lack of willingness by public library managers to implement bicultural or Treaty-based initiatives, combined with a lack of nationwide strategic approach, means that libraries are unable to go to deepen their engagement with Māori approaches, and realise the requirements of partnership outlined in Te Tiriti o Waitangi | the Treaty of Waitangi.

The vast predominance of published literature relates to public libraries, and consequently literature covering the academic library experience in sparse - Tautolo's paper one of the few. Much of the interesting research is emerging from the Masters of Information Studies programme (Hayes, 2012; Tamaira, 2007; Tuhou, 2011).

\section{Māori Information Needs}

Both Szekely (1997) and Simpson (2005) in their findings note information needs and search patterns that may be specific to Māori communities, including issues such as: the need to access information in Te Reo Māori or about whakapapa, the desire to use source manuscripts and the importance of primary sources, a preference for dealing first with people, and more specifically with Māori staff to access the information they need are all mentioned in these findings, and a preference for browsing the shelves rather than using the catalogue. At the same time, participants in the Guiding Voices hui (1997) noted that Māori information needs are as diverse as any other peoples. Consequently, it seems advisable to be careful in taking these as clear markers of specifically Māori information needs and search patterns.

Lilley $(\mathbf{2 0 0 8})$ in his research with Māori secondary school students found that his participants expressed preferences for seeking information from interpersonal sources, and that the particular people who are sought vary depending on the informational context, for example in a Māori 
cultural context, kaumatua $\mid$ elders and parents might be preferred. In addition, Lilley found those with strong cultural identity indicators (for example, speaking and understanding Te Reo Māori) experience fewer information barriers across different cultural domains of information searching. This echoes Sir Mason Durie's framework for Māori educational achievement (2001), in which he describes a key goal of education is to be able to 'live as Māori'.

Lilley has also written more generally about Māori and Information Literacy $(\mathbf{2 0 0 0})$ while Moata Tamaira has examined the information needs of whakapapa researchers in the public library context (2007). However, there seems to be little if any research into particular information needs of Māori students at the tertiary or university level.

\section{Māori Pedagogies: Teaching and Learning with Māori Students}

Rangimarie Rose Pere in her seminal work Ako (1982), outlines a number of important qualities of traditional education among some hapū and iwi Māori. In his later survey of Māori pedagogies, Wharehuia Hemara (2000) examines both contemporary and historical literature. Both authors offer insight into Māori teaching practices, both current and ancient. Some of the key practices that they noted included:

- the use of multiple media in teaching-including whakapapa $\mid$ genealogy, whakatauākī proverbs, waiata $\mid$ songs, whaikōrero $\mid$ speechmaking, and kōrero tawhito $\mid$ ancient histories ;

- cooperative, reciprocal learning for both teacher and student,

- an attentive, individual approach enabled by modest student-to-teacher ratios leading to a mutual relationship, and the teacher's deep knowledge of the particular skills shown and challenges faced by particular students,

- an engagement with meaningful tasks, and imitation of real world behaviours; mutual relationship between teacher and student;

- $\quad$ self- and peer-evaluation of learning and progress;

- intergenerational and lifelong teaching and learning;

- learning incremental and familiar; 
- use of metaphor and allusion.

Elements of these will inform the teaching and learning approach in this project.

A powerful, practical and contemporary approach to teaching and learning with Māori students is found in Te Kotahitanga, a project which seeks to apply kaupapa Māori education practice to mainstream classrooms in Aotearoa secondary schools (Bishop, Berryman, Cavanagh, \& Teddy, 2007, 2009; Bishop, 2008) The project draws on Graham Smith's six kaupapa Māori principles (2003) as foundational metaphors for developing what the authors name 'a culturally responsive pedagogy of relations' (Bishop, 2008, p. 446) The principles: self determination | rangatiratanga; cultural aspirations $\mid$ taonga tuku iho ; reciprocal learning $\mid$ ako ; mediation of social and economic difficulties | kia piki ake i nga raruraru o te kainga ; whanau | extended family are echoed in some of Lilley's work (Roy et al., 2011). In putting these principles into practice, Te Kotahitanga commenced by gathering narratives from Māori students about their classroom experiences, to redress the usual imbalance of power between teacher and student, and to foster student engagement. Perspectives were then sought from whanau, principals and teachers. These were developed into and effective teaching profile to support the professional development of teachers teaching Māori students. Key findings reinforced the foundational metaphors: emphasising the importance of avoiding deficit thinking, which placed responsibility for Māori students educational underachievement primarily at the feet of the students Through the effective teaching profile and other engagements with staff, the project seeks to change the learning relations in the classroom, seeing this as key to supporting learning for Māori students.

This literature reinforced Lilley's approach to developing effective teaching and learning within the library. The next section examines what it is that needs to be taught and learnt.

\section{Information Literacy}

Information literacy (IL) has become increasing prominent in the work of academic librarians in the last decade, reflecting what Elmborg describes as a move from 'service provider' to 'active educator' involved in planning and delivering academic instruction alongside academic staff $(\mathbf{2 0 0 6})$.

In an oft-cited definition, the American Library Association (ALA) Presidential Committee on Information Literacy described the information literate person as someone who could: 
effectively the needed information (American Library Association, 1989).

This functional skill-set is further examined and developed through the library literature, commonly connected with other skills or literacies including: to lifelong and independent learning, to fluency with information and communications technology, and to critical thinking and reflective practice (EImborg, 2006; Vezzosi, 2006, 2007). Standards have also been produced which articulate the necessary competencies required to achieve information literacy (Australian and New Zealand Information Literacy Framework: Principles, Standards and Practice, 2004; SCONUL Working Group on Information Literacy, 2011).

Vezzosi (2006) and Elmborg (2006) point out, however, IL has been a much debated topic and its definition remains contested.

\section{Critical and Cross-Cultural Definitions}

Of particular interest to this research, are authors such as Swanson $(2004,2005)$ and Elmborg (2006) who argue for the need to engage fully with educational pedagogies and critical theory when defining IL. Like education, IL performs political and social functions and exists in a cultural and historical context. It is disingenuous to describe it simply in mechanical and technical terms, as they are skills that express a particular cultural perspective.

This thinking is further developed by authors like Beatty (2007) and Roy, Lilley and Luehrsen (2011) . Beatty discusses cross-cultural information literacy teaching and learning at Dine, a Navajo college in Arizona. She discusses the importance of learning from indigenous knowledge frameworks, a relationship-based approach to teaching and learning with students, describing IL as 'a lifetime habit of mind', and rendering it in the plural, as information literacies. Both these papers emphasise the necessity of both 'western' and indigenous knowledges in information literacy teaching.

This is a key development for this project, and together with the research framework outlined following this literature review, will form a vital part of the planned information literacies teaching and learning session.

\section{IL in Academic Science Libraries}

The literature examining IL within a context of tertiary study in sciences offers three interesting themes: the importance of curriculum design and of embedding information literacy into course 
programmes, the need to develop and maintain relationships with staff, and the importance for IL to be discipline specific in order to retain meaning.

Smith (2003) advocates for a discipline-specific information skills programme in sciences, offering specific proposals for undergraduate information skills instruction including advocating for embedding information skills instruction within the science curriculum at universities. In a case study of a 2004 curriculum redesign in Biology at a North American university, Firooznia and Andreadis (2006) echo Smith's emphasis on the importance of embedding information literacy instruction into disciplinary curricula, and go on to describe the structure of the course and identify specific elements of instruction. Manuel (2004) discusses the tensions between 'generic' and 'discipline-specific' information literacy competencies, emphasising that information literacy standards need to be placed in disciplinary context in order to be meaningful.

These themes fit well with Beatty (2007) and Roy et al. (2011) investigation of library teaching and learning with first nation American and Māori students. While describing it in slightly different terms, each acknowledge the importance of relationships to information literacy teaching and learning. Each also acknowledge importance of context, making space for a conversation between different frameworks: generic and disciplinary specific in one, and 'western' and indigenous in the other. Both seem to suggest the importance of weaving different contexts together to support the academic success of the students concerned.

Weaving together all the elements in this literature review, there is clearly a gap concerning teaching and learning information literacies with Māori students, and the specific forms that might take. While it is mentioned both by Lilley (2000) and Lilley and Field (2005), neither of these address the specifics of teaching and learning IL with students. While Pukepuke and Dawe (in press) is the only literature I could identify that specifically examines a tau iwi librarian teaching information literacy and supporting Māori(and other) students in an academic context.

There is important work being done to reduce barriers and develop services for Māori in libraries. There does seem to be space for further development and deepening of library engagement with Māori, particularly around library teaching and learning. Particular teaching and learning methods that best support Māori learners connect well with some cross-cultural and critical understandings of information literacy teaching from the library literature. However, there is definitely space for specific investigation of teaching and learning information literacy in a cross-cultural context. This may have value for the library profession as it seeks to deepen their partnership with Māori under Te Tiriti o Waitangi | the Treaty of Waitangi. 


\section{Research Framework}

This research is positioned towards and away from certain outcomes - it is neither neutral or objective. It assumes both the importance of ongoing support for Māori students in academic libraries, and about the need for pākēhā and tau iwi librarians to do this work alongside and in support of their Māori colleagues. The research framework draws on the work of Linda Tuhiwai Smith and Sir Mason Durie in particular.

\section{Weaving a whāriki | Stitching a quilt}

This project was inspired initially by the Kaupapa Māori theory and research philosophy in the work of Linda Tuhiwai Smith (2012) and Russell Bishop (2008). This seemed a strong and vital approach grounded in Māori worldviews that had much to teach librarians seeking to actively support Māori students to succeed at University. As the project went on, conversations with colleagues and friends both drew my attention to the work of Prof. Sir Mason Durie and his model of 'Research at the Interface' (Durie, 2004, 2005), and encouraged me to bring in my own background as a Treaty educator and activist. The following research framework is an attempt to weave all these elements together in a quilt or whāriki.

\section{Kaupapa Māori Theory and Research}

Emerging from autonomous Māori community initiatives in education, like kōhanga reo, kura kaupapa Māori, kaupapa Māori theory weaves critical theory with lived realities of whānau, hapū and iwi Māori as indigenous peoples in a colonised Aotearoa to produce a critique of and resistance to the dominance of colonial pākēhā knowledges. While it is difficult to find concise definitions, one definition offers a compass with three key directions: that Māori ways of being and knowing are legitimate; that the survival of Māori language and culture is imperative ; and that struggle for autonomy over cultural wellbeing is vital to Māori survival (International Research Institute for Māori and Indigenous Education, 2004).

Developing from this approach, Kaupapa Māori research seeks to ensure the development of whānau, hapū and iwi Māori as Māori, while also acknowledging the painful and alienating effects that research has had on many indigenous communities. It is a way of engaging with research on Māori terms that seeks transformative outcomes for Māori communities participating in research (G. Smith, 2012). Linda Tuhiwai Smith notes that 'aroha ki te tangata' (a respect for 
people), and 'kanohi kitea (the seen face, that is present yourself to people face to face)' (2012, p. 124) are two elements of this sort of research.

There are ongoing debates about whether or not Pākēhā can do Kaupapa Māori research, or participate prominently in Kaupapa Māori projects. Some scholars have described Kaupapa Māori as necessarily for Māori by Māori (L. T. Smith, 2012), pākēhā involvement risks re-enacting pākēhā control and undermining tino rangatiratanga $\mid$ sovereignty in situations which are not about or for pākēhā (see for example Jones, 2012; G. Smith, 2012). I did not wish to entangle myself with those debates, but I was inspired in my own path by this approach.

\section{Research at the Cultural Interface}

Sir Mason Durie's model of 'Research at the Interface' $(2004,2005)$ addresses the interface between different knowledge paradigms - Mātauranga Māori and Western Science - and how that might influence a research process. He describes the space where indigenous knowledges and science meet as potentially productive and 'aims to harness the energy from two systems of understanding to create new knowledge that can be used to advance understanding in both worlds' (Durie, 2005, p. 306). Sir Mason outlines four principles for learning and research at the interface: mutual respect; shared benefits; human dignity, and discovery. Sir Mason's work shares elements with that of Torres Strait Island researcher Martin Nakata, who names 'the intersection of 'Western' and indigenous domains, the 'Cultural Interface" (2002, p. 28). According to Nakata, this is where indigenous peoples already always live and learn, that is 'a place of tension that requires constant negotiation'.(2002, p. 28). This seemed incredibly apposite for my research as it sought to address not only an ethical engagement between Māori and Pākehā in a research space but also a mutually-respectful encounter between 'Western' knowledges and Mātauranga Māori.

\section{Working as an Ally}

This research also seeks to incorporate my modest experience as a Te Tiriti o Waitangi $\mid$ Treaty of Waitangi educator, and in particular the importance of pākēhā and tau iwi taking responsibility for their own work in their relationships with Māori. For me, this means reflecting on my cultural position and privilege, and seeking to relate with Māori in ways that acknowledge grief of colonisation and its ongoing consequences for us all - relations that do not elide histories of loss, violence and suffering. This draws on the work of Robert and Joanna Consedine (2005) and of 
Jen Margaret (Margaret, 2010). In describing possibilities for pākēhā action to support Māori, Margaret uses the term ally. This is drawn from the tradition of those settler peoples working to support indigenous peoples, and oppose racism in the United States. Margaret describes the ally role as relationship-based and dependent on context, and may require the playing of various roles. The work of an ally demands both the ability to listen carefully and maintain critical selfawareness, and is learnt through practice, through conversation, through humility, and sustained through groundedness in ones own traditions.

Each of these three approaches contribute to the research methodology, and I hope that through the use of these frames, the research will contribute to transformative and engaging library practice.

\section{Research Principles | Kaupapa Rangahau}

The research took the following principles as its foundations:

- interface: research by a pākēhā librarian with Māori staff and students happens at the intersection of multiple knowledge paradigms - Māori and Pākēhā; Mātauranga Māori, Western Science, and Library and Information Studies; Education, and that all have something to contribute to supporting Māori academic success

- educational interface: the University is another site of the 'cultural interface', and that this research seeks to affirm the importance of Māori cultural knowledge and ways of knowing in the University and library environment, while acknowledging the importance of students learning to navigate University protocols and practices, including those of the library;

- mutual benefit: the benefits of research must be shared, in this case seeking to support good academic outcomes for Māori students in Sciences and beyond, while supporting librarians to improve library services for Māori;

- collaboration / connection: despite being the primary investigator in this research, the project was always already a collaborative learning exercise as much as an investigation. It is ultimately about people, and is enabled by and strengthens existing relationships between myself, the library and Māori staff and students, and seeks to work with Māori staff and organisations on campus.

- discovery: the space where the library, western science, mātauranga Māori $\mid$ Māori 
knowledge and tino rangatiratanga $\mid$ autonomy meet is a potentially productive area and stitching or weaving elements of these areas together will require exploration and invention, that seeks to benefit all. 


\section{Methodology}

This research project is an exploratory study in a university library context, tightly scoped owing to its modest timeframe of two University trimesters, a little under seven months.

\section{Action Research}

I chose an action research methodology, as this was consistent with an approach taken by other librarians in reflecting on and improving their teaching and learning practice (Pickard, 2007; Vezzosi, 2006, 2007). Action research is an interventionist research approach, that sees 'no separation ... between the design and delivery of teaching and the process of researching these activities' (Vezzosi, 2006, p. 290). As its name suggests, it focusses on reflection and action of teaching and learning practices, rather than simply critiquing, analysing or theorising about those practices. It fits well with the current need for constant improvement of library services. Its threefold aim is to improve library practice through critical reflection, to improve the practitioner through reflective practice, and to share the findings with colleagues for the improvement of the library profession as a whole. While challenging, it is a way of examining my place of work and my own practice as a librarian, and might be described as research both in and out of place, offering elements of an insider and outsider perspective.

Action research is a cyclical or spiral approach to research with four basic stages: observe, plan, act, evaluate. The evaluation stage then feeds back into the next cycle beginning with further observation. This method also seems consonant with cultural interface and kaupapa Māori work: that acknowledges participation, or active engagement between researchers, participants and learners.

\section{Investigating Teaching and Learning Information Literacy with Māori Science Students}

This project was intended to take place in three stages: initial discussions with Māori staff and senior Māori students in the Division of Sciences to identify the issues and inform and enable the planning of the information literacy skills teaching session; a session that would be delivered to students; and an integrated evaluation of the teaching session done by the students in dialogue 
with the researcher.

Due to time constraints preventing the important work of establishing relationships with students, only the first stage was able to be undertaken, and its findings are reported here. I have also included reflections on the research process that I believe might contribute to the development of future research.

\section{Observe \& Plan}

The first stage of this project involved the researcher facilitating hui and semi-structured interviews with Māori staff and postgraduate students within Division of Sciences at the University of Otago in April 2013. I then incorporated the preliminary findings in these hui into a plan for an information literacy skills intervention, which is included as Appendix Three.

\section{Sampling and Participants}

I recruited participants in the study through existing relationships and professional networks in the University and Division of Sciences. This was a purposive, non-representative sample of Māori staff and senior students that were grounded in the desire to honour the relationshipbased way of working. While this certainly challenges the objectivity and generalisability of the process, much was gained by the existing relationships enabling frank discussion of the library and student support. A final total of six participants were all female, despite attempts to include males in the invitations, and included: academic staff involved in teaching, research and supervision; staff working in student services and support both in the University generally and in the Division of Sciences; and postgraduate students at the beginning and at the end of their research.

\section{Hui Kōrerorero and Interviews}

Hui kōrerorero $\mid$ focus groups were initially chosen as a relevant and effective method to engage with staff and students as they enabled a collaborative, conversational approach. The hui were arranged and took place at Te Huka Mātauraka, the Māori student support centre at the University of Otago. This was consciously chosen as a space were both staff and students might feel more comfortable than at the library. Interviews took place in participants' offices.

The hui were structured to reflect aspects of tikanga Māori: opening and closing with karakia blessing, making space for introductions and (re)establishing a relationship | whakawhanaungatanga, followed by kai $\mid$ food, before proceeding to the main discussion. The 
follow-up interviews were not. An outline of the hui process is included as Appendix Two.

Participation in the hui was less than anticipated with two Māori staff and two senior Māori students (from the same department) attending. Follow-up interviews were then conducted with two further Māori staff who were unable to attend the hui but willing to contribute, making a total of six participants in the observation stage.

The audio for both hui and one follow-up interview were recorded, and notes were taken during all encounters. Both hui and interviews discussed the challenges faced by Māori students in the library, support and library information skills needed by Māori students, as well as the relevance of the proposed indigenous approach information literacy skills teaching and learning intervention. The guide and questions were taken as a beginning point for discussion, rather than strictly followed, in keeping with the fluid and relationship-based nature of the research. This flexibility combined with low numbers of participants, may have enabled the breadth and depth of the discussions that took place.

\section{Analyse}

Following the hui and interviews, I did a rough transcription of the three audio recordings that I had made. I listened through to the hui and interviews, read the transcripts alongside the notes I made to get the overview of what was said. I then coded the data following a standard three-stage coding process: open, axial, selective. After initial listening and reading, preliminary themes for the hui and interviews began to emerge and were noted. Following initial identification, themes were reviewed, organized, and revised. Finally, specific cases and quotes that illustrated the revised themes were chosen.

From the coding, the following themes were identified:

1. The Challenges of Crossing the Threshold

2. Sustaining Student Engagement

3. Weaving continuing relationships of mutual benefit and respect

4. Holistic Development and Advocacy

5. Acknowledging Student Diversity

6. Teaching for Effective Learning

7. Te Library Stuff : greetings across the threshold 
8. Getting to Information Literacies

Although the plan for a teaching and learning intervention with students was not able to be enacted, it was conceptualised through this process of analysing the data and drawing out the findings. 


\section{Findings and Discussion: Observation and Planning}

Low numbers of participants mean findings are only preliminary and may not be applicable beyond their immediate context. Further investigation would of course be necessary in order to test this. I do, however, consider the methodology and research process a valuable one that could be further developed and extended for use by pākēhā librarians working with Māori staff and students.

While the initial aim of this project was looking at information literacy teaching and learning with students, the conversations in the hui and interviews were broader than that. It also became clear during the project that there were several steps that needed to be taken inside and outside the library for the work of teaching information literacy to be relevant at all.

\section{The Challenges of Crossing the Threshold}

While the research did not focus on barriers to Māori student use of libraries, one initial challenges noted at all hui and interviews by staff and student participants was actually getting Māori students 'across the threshold' i.e. into the library for the first time. Before discussing teaching and learning support, services or collections, participants talked about the challenge of simply entering the library. A key reason given for this was a sense of the students's being whakamā. Dame Joan Metge (1986) defines whakamā as encompassing feeling embarrassed, shy, uncertain, ashamed, inadequate, and hurt. Participants described the difficulty that some Māori students have in even engaging with the library:

One of the challenges that I'm realising, with not just accessing the Library but across the campus, with first years is this sense of being whakamā, that's intrinsic in a lot of our people, and so with that is that [not] being able to cross the threshold even to talk to you... in trying to get them across that threshold initially and actually get them in the door. [Participant - staff]

'Cause I didn't really approach anything, but that was probably because I was shy and didn't know where to go for help. And I was too shy ... if I did get told, it was just the general direction, and then I was way too shy to just go in that general direction. [Participant - student] 
Some Māori students are uncertain of how to approach the library, or even to enter it at all. This noting of challenge of entering library space, of first encounter with the library was strongly linked to discussion of the importance of relationships and advocates, both in terms of getting the students to the library initially and then sustaining their engagement with the library, its space and resources. It was also acknowledged that the space is both a physical and a virtual one.

It was noted by several participants that early engagement with Māori students, in their first weeks, with one suggesting both engaging with students before they arrive at University (as the Division of Sciences at Otago do with their Science Wānanga) and then once the students do arrive, making the Library a part of the initial powhiri for Māori students and their whānau in orientation week. Participants also made comment about the importance of normalising the library as part of the academic experience, so that it becomes something that students expect to do.

\section{Sustaining Student Engagement}

One participant made a distinction between the initial approach to the library for Māori students - getting 'across the threshold' - and continued engagement - ongoing relationship - making explicit the difference between getting students to the library and keeping them there:

\section{It's sustaining that engagement. It's getting them in the door and then to sustain that engagement... [Participant B]}

This opened out into a discussion of the cultural quality of library space, of the need for a 'Māori face' and perhaps Māori-centric design in the library.

Within the theme of sustaining engagement and supporting students effectively, a number of participants discussed the merits of making engagement with the library and/or library research skills compulsory. Several possible means of doing this were canvassed: integrating them with course teaching, linking them with internal assessment, embedding them into the curriculum in tutorials and labs :

What could be quite good is when people sign up for those tutorials, if the very first tutorial is 
actually not their subject topic, but taking an introduction to the library and the services that are ...

Yes, that's right, to make it normalised within ... because it crosses all divisions, all papers, all subjects ... you name it, it crosses it. [Participants A \& B in conversation]

Conversations in the second hui reinforced this:

Definitely I understand what you are saying there...just.. like almost they need to be put in a place where they have to use it... and they have to go through it, and not by choice, because if ... it's the people who wont choose to do it that need the help. The ones that are motivated would do it.

That's right, they'll go and search it out before even school starts. It ought to be integrated actually alongside the curriculum. I can only say that with Psychology, that there be some sort of like sustainable programme where the library sits alongside the department, where they can introduce APA at quite an get go ...

The first lab or something. [Participants C \& D in conversation]

This talk of 'embedding' or 'normalising' the services and resources that the library offers was picked up in other hui and interviews, with participants seeing it as important to embed the library into the routines and expectations of Māori students at University. This will be picked up again in the next segment.

The quality of staff engagement with the students was also raised by several participants, with participants noting the importance of helpful frontline staff, and of knowledgeable, critical and engaging questions to draw the students out in their search for information:

First approach doesn't have to be lengthy,just engaging and helpful. [Participant C]

Possibly some of our staff need to be provided with some resource ... some further training or resourcing with asking critical questions that will be able to ensure that the student gets. .. is able to access the resource. [Participant D]

This intertwines with one of the most significant and recurring themes in this research; that of 
the importance of ongoing relationships with students.

\section{Weaving continuing relationships of mutual benefit and respect}

Participants in the project spoke of how important connectedness and ongoing relationships are in enabling the Library to effectively support Māori students. The need for face-to-face, personal engagement with students was emphasised, as was the importance of a familiar face $\mid$ kanohi kitea in aiding students to feel comfortable enough to engage with the Library or ask questions:

Kanohi ki te kanohi, the face-to-face interaction is key. [Participant A]

There's a phrase that's used in Maori and in English it is : 'once a face is seen, never to be forgotten', and so with the kids, there's lots of things when I've been out in the field and they see me back here, and they say I remember you, and the same could be said for yourself or one of your colleagues doing that walking the talk. [Participant C]

The need for ongoing relationships was also touched on, with one participant noting:

So also if the students know that the relationship is ongoing, beyond just can you help me get my book out. [Participant E]

These statements clearly call for something beyond a simple, discrete customer-oriented transaction with a library user, but something that is developing deeper and more sustaining connections with the library staff themselves. It seems to contradict the functional-transactional customer service model adopted by public and academic libraries. The challenge might be to create spaces that enable fruitful exchanges and ongoing relationships, rather than customer service transactions.

Other comments that intertwined with these, were those remarking on the importance of building capacity within the library to further enable those relationships. This must include recruitment, development and retention of Māori staff within the library, of visible Māori faces, but also needs to encompass the professional development of Pākēhā and other Tau Iwi staff in Te Ao Māori, as well as. A positive consequence of this would be that students could see a place 
for themselves in the library, not only as library users but also as staff.

Discussion about the need for ongoing, reciprocal relationships touched on engagement with iwi and hapu to ensure that all the resources that they are producing are available in the Library. It was also noted that librarians are powerfully positioned to act as connectors, putting students in touch with appropriate people and information across disciplines.

Many of these participants' perspectives find echoes in the library and education literature, not only in terms of engaging with Māori students but also in engaging with and effectively serving students generally.

It certainly resonates with Massey University Library, Manawatu team's identification of key principles that underpinned library support for Māori students, including whakawhanaungatanga the developing of connections, which in turn enable students to feel more comfortable in approaching staff (Roy et al., 2011). Tautolo (2012) and Pukepuke and Dawe (in press) also discusses the importance of trusting relationships in working to improve support for Māori students in the library. Personal, trusting and reciprocal relationships also mean that the 'librarian can seek answers from patrons' (Tautolo, 2012).

In describing the education research project, Te Kotahitanga, which seeks to implement a kaupapa Māori approach to teaching in mainstream secondary schools in Aotearoa, Russell Bishop discusses the use of whānau as a metaphor for types of relationships in the classroom, that are committed, connected and foster mutual learning. He emphasises that 'connectedness is fundamental to relations' (Bishop et al., 2007; Bishop, 2008).

Read together, these perspectives reinforce that presence and respectful ongoing relationships may be important to Māori students. This sort of relationship, however, can not be contained within a detached professional transaction. Further, these relationships do not exist solely online, in mediated or asynchronous environments, such as Blackboard or Facebook. They are nuanced, and layered, and involve ongoing commitments and at least some willingness to be physically present with one another, to share space, to meet kanohi ki te kanohi.

It is particularly interesting to weave discussions about the importance of relationships with the 
literature about placing librarians at the heart of curriculum development and departmental course teaching. Delving deeper into the library literature, we find that the library discourse of 'embedding librarians' may have parallels to this relationship-based approach to academic librarianship (see for example Dewey, 2004; Pritchard, 2010).

\section{Holistic Development and Advocacy}

Connected to this question was another significant aspect that came up in the conversation with some participants was the role the library in supporting the development of the students as whole people, grounded not only as students or emerging researchers, but as Māori. This might link with the library discourse about lifelong learning, or it might be termed pastoral care, or attention to the wellbeing of the students. One participant talked about taking an holistic and strategic approach to supporting students, and seeking to spark and nurture their passion for particular areas of research, to light a fire of interest in particular learning. It was suggested that the library had a role to play in supporting that.

This is reinforced in the work of Sir Mason Durie (2001), who in discussing a frame work for Māori educational advancement writes about goals of both being able to live as Māori, and to actively participate as citizens of the world, and about the principle of ensuring the best outcomes for Māori students.

Further to this, several participants spoke of connecting students with research being undertaken by hapū and iwi, both to develop their engagement with research and with issues of currency, but also to support their contributing to the development and sustenance of their own whanau, hapu and iwi. Connected to that was the suggestion to bring practitioners working in particular fields, to the classroom to advocate for the use of the library:

And there's another idea about actually bringing in people... so if it's a diabetes thing, bringing in someone who is actually in that career right now. And seeing that pathway in the library and how did that person get to that pathway through the services like the library perhaps, as your way of advocating ... a winning ... [Participant B]

Part of the aim according to one participant is to enable the students in a purposeful search for knowledge. The library could enhance the cultural capital of the students, by strengthening their 
ability to operate comfortably in and move between two paradigms and worldviews. Another part of this is supporting and helping Māori students to gain the skills they need to move into postgraduate study. Several participants noted that in order to move through into that further study, even senior students themselves articulating the need for normalised, early-led library skills that can support students to develop capacity and passion for higher level research.

Librarians were also described as being uniquely placed to connect students to other people or services in the University, if questions or particular sorts of support were beyond their expertise to answer or offer:

The other thing that I thought would be really cool to have in the library is that ... when you're a student and you're doing sciences and you're still young but you haven't quite decided where it is that you might head, or even if you are thinking about research or thinking that I didn't get into Med I wanna ... i'm interested in following this ... who to go and talk to about it, and the librarians could be ... I mean there's always [Division of Sciences Associate Dean Māori and kaiarahi], but you know you're Sciences so maybe the librarians could get hooked up with key people who would be happy to speak to the Mäori students or maybe meet in an office hour or something for them just. Maybe you could help them pick up the phone, help them make the call, cause if they're whakamā...

Yeah, having that strong deliberate link to the different divisions or departments.

Or sources of information that you can't find ...

Or the external community: [Participants A \& B in conversation]

So library staff are described as having a key role, one that is much broader than a transactional customer service, but might incorporate pastoral care, lifelong learning support, or even career advice. This connects to the principle of tautoko $\mid$ support in Lilley's work (2011)

\section{Acknowledging Student Diversity}

Several participants emphasised the diversity found among Māori students, in terms of their academic skills at the point they reach University, the path their academic journey takes, also in 
engagement with their whakapapa Māori, their knowledge of te reo and tikanga, and their preferred learning styles. It seems facile to say it, but Māori student cohort are just as diverse as any other student cohort.

In a discussion of the challenges for Māori students in the library, one participant commented:

It depends because the students are diverse as well.I mean diverse in their Mäori identity, I suppose, but also diverse in the subjects they study, and their ... maybe not willingness, but their ... not even access to the library ... then whether or not their ... how much they want to study. [Participant E]

As Māori students are a relatively small percent in the proportion of students enrolled in University courses - 10\% of national EFTS, and 8\% of University of Otago EFTS in 2011 (Tertiary Education Commission, 2012), it might be tempting to make assumptions about their level of academic ability and the level and type of support their require from the library. This was reinforced as incorrect and unhelpful in the hui and interviews.

Participants emphasised that Māori students at University will vary across academic programmes in terms of academic ability and engagement. Just as pākēhā and other tau iwi students, Māori students will vary in their preferred learning styles, and will not all fit the stereotype of 'Maori as kinaesthetic learners'.

Their backgrounds and achievements will be diverse, some will be school leaders, high achievers, captains of sports teams, others might struggle in the transition to the academic expectations of University. Some, perhaps particularly those who have come through Kura Kaupapa and Wharekura schools, will be strong in their Māori identity, their te reo Māori and tikanga, while others are just beginning that journey.

Several participants noted the challenge for students of negotiating their Māori identity at University (as elsewhere), for some they may feel conscious of 'not being Māori enough', while another participant noted that some students coming from a rich Māori environment might carry a heavy weight of whānau expectations with them.

Increasingly, the University is welcoming students who have graduated from Kura Kaupapa and Wharekura, Māori-medium primary and high schools. This may mean that writing and submitting assignments English is a challenge for them, and that they wish to submit assignments in Māori, which brings new challenges and requirements for support not only from the Library but all across the University. 
Several participants emphasised the need to avoid the deficit mindset when planning to support Māori students. Deficit thinking about Māori students is powerful and can be hard to shake. It encourages pākēhā librarians to expect Māori students to need a certain kind of support, to behave a certain way, or have certain cultural expertise. This thinking may demean and other not only Māori students, but staff with whom we might seek to work. This again finds echoes in Lilley's work, connecting with the principle of mana $\mid$ enhancing pride or prestige. It also connects strongly with the findings in Te Kotahitanga about the destructive effects of deficit thinking (Bishop et al., 2007; Bishop, 2008).

\section{Teaching for Effective Learning}

When discussing teaching and learning with Māori students, one participant recommended collaborative and flexible approach, one that sought to engage with the perspectives of the students themselves:

You want a collaborative approach. Collaborative approach requires you to know what you're doing, so it doesn't seem like you're winging it. And you know everything about the library... [Participant E]

This collaboration may be more difficult and even more important in the library context where much teaching is once off. Further discussions of what types of teaching and learning might work best for undergraduate Māori students in Sciences found a variety of responses. These included: employing a clear and simple kaupapa | framework, that could then be looked at from different angles; using humour; striking a balance between informal and formal; clearly linking the teaching and learning to assessment, and / or embedding it in the curriculum; engaging with different learning styles. These discussions echo and are reinforced by the work of Pere (1982) and Bishop (2008) around Māori pedagogies.

In one hui, the power of peer learning and support for students was emphasised:

So, I was thinking about what we have been doing lately with our peer facilitation, and in terms of delivering it. It seems to be facilitated better peer-to-peer whatever it is, whatever the subject is. 
That does work. Because we tried [different ways]... that ... yeah, nah. This process here peer-topeer seems to be working. So in identifying what the needs are, I agree with [Spencer Lilley's approach], so the manaaki and whannaungatanga is intact. And that all relates back to that being. comfortable in that ensironment. And then you'll retain them, if you can get them through the door with that , they'll come back for more. [Participant E]

This was presented as an effective way to engage with the students initially and to ensure their ongoing engagement. This finds support in Lilley's on Māori information needs and the work of Spencer, who research with Māori secondary school students found that students were most likely to seek information from friends, family, and other close personal contacts.

Other participants noted the power of connecting students to graduates practicing in their chosen field who could engage and inspire students and at the same time advocate for the importance of the library. Another participant suggested using whakapapa as a way of structuring teaching; giving the cultural and historical context of the university, of the library for the students.

\section{Te Library Stuff: greetings across the threshold}

Early in 2012, before this project emerged, I worked with the Māori Resources Portfolio Librarian to develop a introductory class for Māori students as part of an academic orientation programme at Te Huka Mātauraka. Together we developed an approach, taking Spencer Lilley's work as a starting point, which we titled 'Te Library Stuff', seeking among other things, to use humour to combat stereotypes about librarians. The approach involved a basic orientation to library services and a discussion about transition to University study.

As this project developed and my thinking deepened, it became clear that the students might benefit from a layered or multi-step approach to the library. If we were to engage the students in work on information literacies, they needed to connect with the library in a meaningful way first. In fact, these challenges as they emerged in the hui and interviews were much more fundamental: getting them across the threshold, greeting and welcoming them to address any feelings of whakamā, and to enable them to engage and ask questions of staff; making them aware of the services that are on offer, beginning to develop beneficial relationships with staff. 
From observing library collaboration with Te Huka Mātauraka | the Māori Centre at Otago University on Ka Rikarika à Tane | their Māori mentors programme, and also participating and observing work done in the Division of Sciences on Timata Te Pūtaiao, a pilot academic orientation programme for undergraduate science students, the sense of a peer-supported first stage, a ritual of initial encounter with 'Te Library Stuff': a visit to the library with a peer group mentor as was trialled with both of the programmes mentioned.

This 'crossing of the threshold' might address elements that emerged in discussion with participants: orientation to the physical and virtual space, and initiating relationships with desk staff, learning how to using course reserve, making sense of call numbers, booking a group study room. The content can be flexible, and will be determined by learning and listening to the needs of particular students at the point of delivery.

\section{Getting to Information Literacies | Rapunga Whakaaro}

While information literacies helped initiated my interest in this project, they are placed at the end of the findings. They have proved more problematic to carry with me than I expected. While the discourse and practice of IL are important to me as a librarian, I found it difficult to talk with the participants about this. During the hui and interviews, I raised the issue of IL towards the end of the hui or interview, and it was a term which often engendered questioning looks, blank faces, and laughter from participants when asked about it.

As a pākēhā librarian in 'post'-colonial Aotearoa, I also found myself uncomfortable with the term 'literacy/-ies", in a country where as few as three generations ago, Māori children were beaten even for speaking te reo Māori in the school playground, and required to learn to read and speak only in the language of the colonial administration. While of course literacies are vital to much of our engagement with the world, it is not a term we can use without care, we cannot be innocent when talking with Māori students about literacies.

Part of the conversation with participants in the hui involved talking about the particular needs of skills that Māori students require from the library. Participants noted:

- database and catalogue searching

- finding research articles

- finding overviews of topics or introductory sources. 
- referencing and avoiding plagiarism

- tricks for finding Māori resources

Providing some compulsory or course-integrated instruction in the finding, accessing and evaluation of information sources was clearly seen as needed and beneficial by participants. An example if the following discussion about finding research articles:

You know I didn't learn how to find a research article until postgrad, when that could have been a lot more helpful in postgrad, especially to get those extra top marks, just because if you are able to pull out a research article, people are going to be like oh they've done extra work.

You're right actually, it's soft of like going back to base one as an undergraduate student not knowing that these ... being able to find those particular articles relevant to the work that you are doing will basically help to build the story and give you extra grade... a better grade. Yes, I didn't know that either as an undergraduate student. [Participants C \& D in conversation]

While it is possible to trace most of the skills listed above in the information literacies literature, or to map them to the Australia and New Zealand Information Literacy (ANZIL) Framework (Australian and New Zealand Information Literacy Framework: Principles, Standards and Practice, 2004). The skill that is not quite so easily managed within the IL standards framework are the additional challenges for Māori students when they need to access Mātauranga Māori Māori knowledge and information sources, as these may require additional skills or knowledge to locate and access. Participants pointed out that some Māori research may not be published in traditional publishing avenues:

A lot of Mäori research is not really published these days, or it hasn't been published yet, or its difficult to find because it isn't in mainstream journals I think help in the Sciences library with those... I came across something recently that wasn't in Lancet, but was actually in an Iwi mag. It was a Māori Health research kaupapa that we knew had been published. So having those kind of resources available. It makes sense to have some link with the Iwi organisations that are in abundance around this country and ensuring that all those resources that they have are sitting back here at the University that the rangatahi are attending. [Participant B]

Additionally, these materials may be only, accessible in print, and less well indexed in large 
international subscription-based article databases. Search terminology for Māori terms and concepts has been woefully inadequate within library catalogues also, something that was highlighted in the Te Ara Tika Project (Szekely, 1997) and is now being addressed by the ongoing development of Ngā Ūpoko Tukutuku | Māori Subject Headings project (Simpson, 2005).

While these skills listed above are undoubtedly essential elements of a study skill-set, they invite a wider question of what else libraries and librarians need to do to support student learning. What else ought librarians to offer Māori students and staff beyond teaching the particular methods of engaging with that monocultural finding and classifying system.

Seeking to combine the previous discussion of holistic development, with the literature on critical and cross-cultural information literacies, and the role of ally suggest that contextual critical thinking, critical consciousness and the ability to operate successfully at the cultural interface might be key goals for teaching and learning information literacies. The purpose of this teaching and learning is both making space for them to bring their own knowing, but also providing the tools to negotiate the expectations of the world of the University education: mutual learning at the interface perhaps.

This space may be difficult to negotiate, however, and one participant urged particular caution when engaging in this work in the library. They emphasised the importance of clearly communicating to the students that you are not assessing or evaluating students' cultural competencies. 


\section{Act and Evaluate: Incomplete}

I have documented above some of the keys themes that emerged from the observation and planning phase of the research. Stage two and three were to be the acting and evaluating stages in the action research cycle, and were to involve delivering the teaching and learning intervention designed in the first stage, and then evaluating it with the student participants. I arranged to co-facilitate an information skills session for Māori undergraduate students in Sciences with my University of Otago library colleague, the Māori Resources Portfolio Librarian. Initial discussions took place with the Associate Dean Māori in the Division of Sciences - who were undertaking a pilot academic orientation programme for first year Māori science students the first year teaching fellow and kaiawhina | Māori student support in the Psychology department, and Te Huka Mātauraka - who run a tutorial programme for Māori students in sciences, including the Health Science First Year programme.

However, due to various challenges coordinating timing in such a time-constrained project, the second and third stages of the project were unable to be undertaken. Part of the reason for the difficulty of enacting the third and fourth stages of the project will be explored in the following section. 


\section{Reflections on Researching at the Interface}

My initial plans for this research were as a three stage of action research study involving teaching and learning with Māori undergraduate students. These could not be carried out, and the teaching and learning and post-evaluation that was planned did not eventuate. Instead, the project involved observation and planning, including undertaking hui kōrerorero and interviews about the library support for Māori students.

Consequently, the process of this research was foregrounded. Instead of focussing solely about the teaching and learning that pākēhā librarians might use to engage and support Māori student achievement in Sciences, I have also reflected on the challenges of undertaking research at the cultural interface between pākēhā librarianship, 'western' science, kaupapa Māori student support, and a 'western' higher learning institution. The following reflections are organised according to themes that emerged through the research process.

\section{Negotiating Layers of Relationships and Research}

This project involved practical and professional difficulty and discomfort in negotiating the complex layering of work, research and study, personal and professional, and cross-cultural relationships. In several senses - as a pākēhā man working alongside Māori staff at a university to support Māori students, as a pākēhā librarian with a deep discomfort with Anglo-American library colonialism and cultural imperialism working in an elite library system, as a humanities and social sciences graduate employed in a science library - I have felt an interloper or outsider without standing in the realms in which I undertook this research. This experience was incredibly helpful, as it has deepened my understanding of what undergraduate Māori students in Sciences might face in confronting the Library, as they undertake their degree course. For in other senses, I am very much an insider, as pākēhā librarian discussing information literacy.

For this project, I was both working and studying simultaneously - studying my place of work, and researching in my workplace. I was, in anthropological terms, researching 'at home'. Working at one higher learning institution, I was enrolled in a course of study at another, which then involved studying my workplace. I was also seeking to work and research as a pākēhā ally with Māori staff and students to support Māori students within a University context. 
The opportunity to undertake this research came about through my position as a liaison librarian at the University of Otago Science Library. Through this and previous work, I had begun to develop relationships with Māori staff and staff in Māori support roles within the library - as part of Te Haumi and as staff at Te Uare Taoka o Hākena, within academic departments in the Division of Sciences - as part of the Kaiawhina network, and in the wider University.

Those relationships of trust and reciprocity were integral to the project, have made it possible. My relationships with colleagues, staff and students were and are both professional and personal, as is my commitment to this research. With my Māori colleagues and research supporters, I had to negotiate multiple roles or layers - friendship, professional support, academic mentoring (but not formal research collaboration) - within a single relationship. This was challenging, confusing and at times frustrating, and yet also involved much fruitful learning.

Collaboration between Māori and Pākēhā in a research and professional context brings the challenge of working in partnership sharply into focus. While it is important to seek to communicate properly, it is also in the tension between our different perspectives that productive exploration happens. Some of this is noted by Alison Jones (2012) who talks about the challenges and discomforts of Māori-Pākehā relationships but urges us 'to remain in positive, engaged struggle together/with each other... eschew[ing] certainty, solutions, and judgment,and embrac[ing] uncertainty, contingency, reflexivity, and engagement'(2012, p. 109).

Perhaps the most significant relationship, however, was the one that was absent: the relationship with the undergraduate students who were a key focus of the project, and yet were present in absentia.

\section{Good Things Take Timing}

One of the foremost challenges in this research was the time constraint. This project was ambitious and required much to be achieved in the short timeframe of two University trimesters, around seven months.

At the same time, the research was neither technical nor quantitative, rather it was founded in establishing and deepening relationships of trust, reciprocity and respect with Māori staff and students - it was both about people and about Māori student success. 
It involved many approaches, some proposing and much listening, checking in, conversing, in person, by phone, over email, in meetings and hui, over cups of tea and coffee. This just to get the first stage of the process underway. To develop and maintain, to be genuinely in-relationship in this way takes time.

And yet, it is the nature and structure of 'western'/pākēhā higher learning institution to instrumentalise time, to compress and segment it, to force it into a linear path. Furthermore, as has been mentioned, this project took place simultaneously within two - one, a place of work, the other, a place of study - both requiring this constraint and compression. These were the deadlines for my research, the cycle of the academic year for potential student participants, and the requirements of my work as a librarian.

Ultimately, it was not possible to complete the full project on or in time, or rather, while it was technically possible, it was not possible to complete it and properly establish the right sort of relationships with the students to ensure reciprocity and trust. Instead, with the advice of supporters, I decided to wait, not to abide by compressed instrumental time. I decided to hold the final section of the project over, to enable it to be done properly at another time.

\section{The Importance of Place}

In reflecting and talking with colleagues before commencing this research, it was clearly important to pay attention to where both the planning hui and the classes themselves were held. With the support of Te Huka Mātauraka | the Māori Centre, I decided to have the hui there. The benefit would be that Māori students and staff might be more comfortable participating and conversing in an identifiably Māori space on campus. Despite the low participation, the wisdom of this choice was reinforced by the hui findings, where the difficulty of getting students across the threshold of the library featured prominently .

While Te Huka Mātauraka (THM) might be culturally familiar ground for Māori staff and students, it was less so for me as a pākēhā librarian. While I have visited THM numerous times, and have known some of the staff for a long time, and worked with them, THM is not 'my' place. I am welcome as a pākehā, but it is not my space, and nor should it be. It is primarily for Māori students.

As we work to make the library more welcoming and comfortable for Māori students,both 
virtually and physically, we must also enter in to their spaces, be present at THM, at Te Rōpū Māori, at hui and pōwhiri. We must continue to be a kanohi kitea $\mid$ seen face in spaces where Māori students feel more comfortable. In going out to meet students, we likely make it easier for them to come to us.

That may mean we step into culturally unfamiliar spaces, that we are whakamā, uncertain, and off-balance, as I have been often in this research. The feelings may lessen, or at least the discomfort will become more familiar, but it is also critical to developing our empathy for and understanding of the journeys that many Māori students must make to study at University.

\section{Conversations and Cross-cultural Communication}

The possibility of genuine communication was both enabled and deformed by a combination of layered relationships, compressed time and (dis)comforting places in this project.

The layers of professional and personal, research, support, and collegial relationships both at times enabled and hindered communication. Assumptions and unspoken expectations proved incorrect or unmet, things went unsaid. The constraints of time and the busyness that everyone faces compounded this.

Walking the lines of cross-cultural communication was vital to the project: seeking to understand the different ways satisfaction or disagreement are expressed; attending meetings and hui and talking things through face to face. Feedback from colleagues emphasised that I needed to do more of that, particularly in the early stages of the project, to hui with all the relevant people and clearly establish a plan for what I was trying to achieve with this research from the outset.

Communication is a many layered process across differing cultural expectations I frequently got it wrong, yet it was vital to keep talking, to persist, to pickup after setbacks, to keep the conversation going. 


\section{Avenues for Further Investigation}

This project has opened many more doors than it could close, and because it is a small and tightly constrained project, there are many options for further investigation.

The most immediate is the piloting and evaluation of the draft information literacies session and evaluation plan developed in the course of this research (see Appendix Three and Four). This could usefully be done as part of normal semester teaching in a liaison librarian role at the University of Otago. It could be co-taught with other librarians to support mutual professional development, and could potentially be embedded in an academic or support programme. Further possibilities that emerge, include:

- investigating how to measure effectiveness of this 'interface' information literacies approach beyond student opinion;

- exploring how the library could welcome and connect with Māori students more effectively in their first year and look at developing 'rituals of encounter at the interface' in both virtual/online and physical spaces;

- examining how storytelling - including Tâwhaki's ascent to the heavens and quest for knowledge - waiata $\mid$ song and whakatauki $\mid$ proverbs might be used to develop effective information literacies learning and teaching. 


\section{Conclusions}

Academic libraries must provide high quality and effective services and support for Māori students that contribute to good learning and research outcomes for those students and for whānau, hapū and iwi Māori. Academic libraries and librarians can improve their support for these students by continuing to develop and evaluate their services and learning from Māori pedagogies and cultural practices.

It must not remain solely the work of Māori staff to provide these services and support. Pākēhā and other tau iwi librarians can act as allies in this process, working alongside and in relationship with their Māori colleagues.

Teaching and learning information literacies with Māori undergraduate students is one vital way that librarians can contribute to Māori student success. Far from being peripheral to the learning experience, they must be brought into the centre of learning. In order to do this, however, information literacy cannot be taught as a set of objectively applicable technical-functional skills. Instead, it must be defined critically and contextually, engaging with and reflecting both 'western' and indigenous worldviews, knowledges and experiences. As Beatty suggests, it must become information literacies.

Librarians can also take useful lessons from Māori pedagogies, research frameworks and cultural practices in how they develop and deliver these literacies. Kaupapa Māori pedagogies, like those outlined by Pere (1982) and Te Kotahitanga project (Bishop et al., 2007; Bishop, 2008) encourage attention to diverse learning styles and learning media, individuality of learners, cooperative reciprocal teaching and learning - the quality of learning interactions in the teaching space. Research frameworks like Sir Mason Durie's Research at the Interface invite us as librarians to inhabit the productive and powerful space where two systems of understanding - 'western' and Māori - meet. By working with mutual respect, ensuring shared benefits, acknowledging different perspectives, we may be able to discover new ways of supporting students and of being librarians. The relationship- and values-based model developed by Māori librarians at Massey University Library Manawatu for developing and embedding information literacies into courses with high Māori enrolment is one such approach, and is helpful and instructive for pākēhā and tau iwi librarians. It takes principles of connectedness, reciprocity of learning, support mechanisms, respect for learners and attention to welcoming as foundations to develop information literacies teaching and learning with students. 
While this project was not completed, its preliminary findings suggest that a two stage process of information literacies teaching and learning would be fruitful and effective with Māori students.

The first stage attends to getting the students 'across the threshold' both physical and virtual and seeking to sustain their engagement with the library through welcoming, orienting and connecting them to peer library users and to librarians. The second stage involves developing and embedding an information literacies curriculum within academic courses and support programmes. Both of these stages would be supported by the Massey Library Manawatu approach and its principles of connectedness, attention to welcoming and respect for learners would strongly support making library space, services and support central to the Māori student experience.

The preliminary findings suggest that this approach would enable students to feel more comfortable coming into the library, better able to seek and be provided with appropriate support. Relationships which are reciprocal and mutual respecting enable more honest feedback and evaluation to further improve effectiveness of services. Professional development advantage for staff is meaningful, connected interactions that both enable staff to see the effect of our support, as well as extend our knowledge through valuing what students can teach us. This is something hard to achieve within a functional-transactional customer service approach to librarianship.

The process of research and of developing relevant services requires librarians to attend to the quality and integrity of their relationships with Māori colleagues, teaching and support staff, as well as with students. Reciprocal, trusting relationships that acknowledge different perspectives and support ongoing conversation will go a long way to enabling this work within and out of the library, however, these take time, presence, and work to establish.

While this work, what I call librarianship at the interface can be challenging, discomforting and even confusing, I suggest that it is through commitment to and practice of genuine and continuing engagement and mutual learning with Māori colleagues that acknowledges and respects our differences - through working as allies - that pākēhā and tauiwi librarians will ensure their own continued professional relevance through providing quality, effective services that support Māori student success. 


\section{Reference List}

American Library Association. (1989). Presidential Committee on Information Literacy: Final Report. Retrieved from http://www.ala.org/acrl/publications/whitepapers/presidential

Auckland City Libraries. (1995). The customer's voice - a quest: a survey: improvement of services to Maori at Auckland City Libraries. Auckland, New Zealand: Author.

Auckland City Libraries. (2002). The Customers Voice: another quest : improvement of services to Maori at Auckland City Libraries : a survey. II. Auckland, New Zealand: Author.

Australian and New Zealand Information Literacy Framework: Principles, Standards and Practice. (2004).

Retrieved from http://akoaotearoa.ac.nz/community/ako-aotearoa-suggested-

resources/resources/pages/australian-and-new-zealand-information-li

Beatty, V. (2007). Much to Teach, Much to Learn:Teaching Information Literacy Cross-Culturally . Paper presented at the Transborder Library Forum: Bridging the Digital Divide - Crossing All Borders, Tempe, Arizona: Arizona State University. Retrieved from http:/www.javiertarango.com/Docs/produccion2007/TRANSBORDER\%20LIBRARY\%20FORUM $\% 202007$.pdf\#page $=59$

Binney, J. (2009). Encircled lands: Te Urewera, 1820-1921. Wellington, N.Z: Bridget Williams Books.

Bishop, R. (2008). Te Kotahitanga: Kaupapa Māori in Mainstream Classrooms. In N. K. Denzin, Y. S. Lincoln, \& L. T. Smith (Eds.), Handbook of critical and indigenous methodologies (pp. 439-458). Los Angeles: Sage.

Bishop, R., Berryman, M., Cavanagh, T., \& Teddy, L. (2007). Te Kōtahitanga Phase 3 Whānaungatanga: Establishing a Culturally Responsive Pedagogy of Relations in Mainstream Secondary School Classrooms. (Final No. RMR840). Wellington N.Z.: Ministry of Education, Research Division. Retrieved from http://www.educationcounts.govt.nz/publications/series/9977/9454

Bishop, R., Berryman, M., Cavanagh, T., \& Teddy, L. (2009). Te Kotahitanga: Addressing educational disparities facing Māori students in New Zealand. Teaching and Teacher Education, 25(5), 734-742. doi:10.1016/j.tate.2009.01.009

Christchurch City Libraries. (2008). Te Ara Hou:The New Pathway - Christchurch City Libraries $\mid$ Ngā Kete Wānanga-o-Ōtautahi Bicultural Action Plan 2008 - 2010. Retrieved from 
http:/christchurchcitylibraries.com/TeAraHou/

Consedine, B. (2005). Healing Our History: The Challenge of the Treaty of Waitangi (Updated ed.). Auckland,

N.Z: Penguin Books.

Dewey, B. I. (2004). The Embedded Librarian. Resource Sharing \& Information Networks, 17(1-2), 5-17. doi:10.1300/J121v17n01_02

Durie, M. (2001). A framework for considering Maori educational advancement. Opening address presented at the Hui Taumata Matauranga, Turangi, New Zealand. Retrieved from http://www.literacyandnumeracyforadults.com/public/files/13093955/Duriemaorieducationalachieve ment.pdf

Durie, M. (2004). Exploring the Interface Between Science and Indigenous Knowledge. Presented at the 5th APEC Research and Development Leaders Forum: Capturing Value from Science, Christchurch N.Z.

Durie, M. (2005). Indigenous Knowledge Within a Global Knowledge System. Higher Education Policy, 18(3), 301-312. doi:http://dx.doi.org.ezproxy.otago.ac.nz/10.1057/palgrave.hep.8300092

Elmborg, J. (2006). Critical information literacy: implications for instructional practice. Journal of Academic Librarianship, 32(2), 192-199.

Firooznia, F., \& Andreadis, D. K. (2006). Information Literacy in Introductory Biology. Journal of College Science Teaching, 35(6), 23-27.

Hayes, L. (2012). Kaupapa Māori in New Zealand Public Libraries (Unpublished Masters of Information Studies Research Project). Victoria University of Wellington, Wellington N.Z. Retrieved from http://researcharchive.vuw.ac.nz/handle/10063/2621

Hemara, W. (2000). Māori pedagogies: a siew from the literature. Wellington, N.Z: New Zealand Council for Educational Research.

International Research Institute for Māori and Indigenous Education. (2004). A Literature Review of Kaupapa Maori and Maori Education Pedagogy. Wellington, New Zealand: ITP New Zealand. Retrieved from http:/akoaotearoa.ac.nz/download/ng/file/group-199/a-literature-review-ofkaupapa-maori-and-maori-education-pedagogy.pdf

Jones, A. (2012). Dangerous liaisons: Pakeha, kaupapa Maori, and educational research. New Zealand Journal of Educational Studies, 47(2), 100-112. 
Jones, A., \& Jenkins, K. (2008). Rethinking Collaboration: Working the Indigene-Colonizer Hyphen. In N.

K. Denzin, Y. S. Lincoln, \& L. T. Smith (Eds.), Handbook of critical and indigenous methodologies (pp. 471-486). Los Angeles: Sage.

Lilley, S. C. (2000). Closing the gaps: Maori and information literacy. Paper presented at the User Education for User Empowerment: Commonwealth Library Association Conference, Christchurch, New Zealand. Retrieved from http://mro.massey.ac.nz/handle/10179/539

Lilley, S. C. (2008). Information barriers and Māori secondary school students. Information Research, 13(4). Retrieved from http://informationr.net/ir/13-4/paper373.html

Lilley, S. C., \& Field, S. (2005). Ki te Ao Marama, Ki te Ao Matauranga : Into the world of light, into the world of information. Paper presented at the Lianza Conference, Christchurch N.Z. Retrieved from http://lianza.org.nz/resources/conference-proceedings/2005/ki-te-ao-marama-ki-te-ao-mataurangaworld-light-world-informat

Manuel, K. (2004). Generic and Discipline-Specific Information Literacy Competencies. Science \& Technology Libraries, 24(3-4), 279-308. doi:10.1300/J122v24n03_05

Margaret, J. (2010, August). Resources for working as allies. AWEA - education for social justice. Retrieved 21 June 2013, from http://www.awea.org.nz/allies_resources

Metge, J. (1986). In and out of touch: whakamaa in cross-cultural context. Wellington [N.Z.]: Victoria University Press. Retrieved from http://otago.lconz.ac.nz/vwebv/holdingsInfo?bibId=13872

Milne, A. (2009). Colouring in the White Spaces Cultural Identity and Learning in School: A Research Report Prepared for the ASB/APPA Travelling Fellowship Trust Following a Study Tour in 2009. Auckland, N.Z.: ASB/APPA Travelling Fellowship Trust.

Ministry of Education. (2008). Ka Hikitia - Managing for Success: The Māori Education Strategy 2008-2012. Author. Retrieved from http://www.minedu.govt.nz/theMinistry/PolicyAndStrategy/KaHikitia.aspx Mulqueeny, N. (2012). Tumeke Bro'? A Personal Reflection of a Male White Counsellor Working with Male Māori Tamariki. Psychology Aotearoa, 4(2), 79-85.

Nakata, M. (2002). Indigenous Knowledge and the Cultural Interface: underlying issues at the intersection of knowledge and information systems. IFLA Journal, 28(5-6), 281-291. doi:10.1177/034003520202800513

National Library of New Zealand. (2006). Te kaupapa mahi tahi = a plan for partnership, 2005-2010. Retrieved 
from http:/www.natlib.govt.nz/files/policy-maori.pdf

National Library of New Zealand. (2010). Bicultural implementation plan, 2010-2012 living draft : summary.

Retrieved from http:/ndhadeliver.natlib.govt.nz/content-aggregator/getIEs?

system $=$ ilsdb\&id $=1396703$

Ngai Tahu Inc. (2006). Ngäi Tahu Education Strategy. Retrieved from http://www.ngaitahu.iwi.nz/Ngai-Tahu-

Whanui/Ngai-Tahu-Education/EducationStrategy.pdf

Pere, R. R. (1982). Ako: Concepts and Learning in the Māori Tradition. Kirikiriroa: University of Waikato.

Peters, S. (2006). Te Ara Tika ki Manukau: Staying the Distance - 2006 and beyond. Paper presented at the

LIANZA Conference. Retrieved from http:/opac.lianza.org.nz/cgi-bin/koha/opac-detail.pl?bib=124

Pickard, A. J. (2007). Research methods in information. London: Facet.

Pritchard, P. A. (2010). The Embedded Science Librarian: Partner in Curriculum Design and Delivery. Journal of Library Administration, 50(4), 373-396. doi:10.1080/01930821003667054

Pukepuke, T., \& Dawe, L. (in press). Creating education spaces for successful indigenous tertiary learners: The TATT Project. ADVANCES in Social Work and Welfare Education. Retrieved from http://www.aaswwe.asn.au/journal.php

Roy, L., Lilley, S. C., \& Luehrsen, V. (2011). Indigenous Cultural Models in Information Literacy Delivery including Programmes for Māori and Pasifika students at New Zealand Universities. Paper presented at the World Library and Information Congress : 77th IFLA General Conference and Assembly, San Juan, Puerto Rico. Retrieved from http://conference.ifla.org/sites/default/files/files/papers/ifla77/94roy-en.pdf

SCONUL Working Group on Information Literacy. (2011). The SCONUL Seven Pillars of Information Literacy: Core Model For Higher Education. Retrieved from http://www.sconul.ac.uk/sites/default/files/documents/coremodel.pdf

Simpson, S. (2005). Te ara tika guiding words: Ngā ingoa kaupapa Māori | Māori subject headings. Pūrongo Tuatoru|Phase Three. Retrieved from http://www.trw.org.nz/publications/Te_Ara_Tika_Guiding_Words.pdf

Smith, E. M. (2003). Developing an Information Skills Curriculum for the Sciences. Issues in Science and Technology Librarianship, Spring. Retrieved from http://www.istl.org/03-Spring/article8.html

Smith, G. (2012). Interview: Kaupapa Maori: The dangers of domestication. New Zealand Journal of 
Educational Studies, 47(2), 10-20.

Smith, G. H. (2003). Indigenous Struggle for the Transformation of Education and Schooling. Keynote address presented at the Alaskan Federation of Natives (AFN) Convention, Anchorage, Alaska. Retrieved from http:/www.ankn.uaf.edu/curriculum/Articles/GrahamSmith/

Smith, L. T. (2012). Decolonizing methodologies: research and indigenous peoples (2nd ed.). London ; New York: Zed Books.

Swanson, T. A. (2004). A radical step: implementing a critical information literacy model. Portal: Libraries and the Academy, 4(2), 259-273.

Swanson, T. A. (2005). Applying a Critical Pedagogical Perspective to Information Literacy Standards. Community \& Junior College Libraries, 12(4), 65-77. doi:10.1300/J107v12n04_08

Szekely, C. (1997). Te ara tika = Guiding voices: Maori opinion on libraries and information needs. Wellington [N.Z.]: New Zealand Library and Information Association and Te Ropu Whakahau.

Tamaira, M. (2007). Searching for Tüpuna: Whakapapa Researchers and Public Libraries. (Unpublished Masters of Information Studies Research Project). Victoria University of Wellington, Wellington N.Z. Retrieved from http://searching4tupuna.blogspot.co.nz/2007_11_01_archive.html

Tautolo, R. C. (2012). Empowering students to achieve: Improving equity of access in the Tai Tokerau Library, University of Auckland. New Zealand Library Management Journal, 52(4). Retrieved from http:/lianza.org.nz/resources/lianza-publications/nzlimj

Tertiary Education Commission. (2012). Tertiary Education Performance Report 2011. Retrieved from http://publications.tec.govt.nz/uploads/Tertiary-Education-Performance-Report-2011.pdf

Tuhou, T. M. P. (2011). Barriers to Māori Usage of University Libraries: an Exploratory Study in Aotearoa New Zealand (Unpublished Masters of Information Studies Research Project). Victoria University of Wellington, Wellington N.Z. Retrieved from http://researcharchive.vuw.ac.nz/handle/10063/1700

University of Auckland. (2013). The University of Auckland Strategic Plan 2013 - 2020. Retrieved from http://www.auckland.ac.nz/webdav/site/central/shared/about/the-university/officialpublications/documents/strategic-plan-2013-2020_web-version.pdf

University of Otago. (2007). University of Otago Māori Strategic Framework. Retrieved from http://www.otago.ac.nz/prodcons/groups/public/documents/webcontent/otago005301.pdf University of Otago Library. (2008). Māori Services Strategy, 2008 - 2012. Retrieved from 
http://www.library.otago.ac.nz/pdf/Maori_Services_Strategy_2008_2012.pdf

Vezzosi, M. (2006). Information literacy and action research: An overview and some reflections. New Library World, 107(7/8), 286-301. doi:10.1108/03074800610677272

Vezzosi, M. (2007). Action research and information literacy: a case study at the University of Parma. In E. Connor (Ed.), Evidence-based librarianship: case studies and active learning exercises (pp. 19-40). Oxford: Chandos.

Walker, R. (1990). Ka whawhai tonu mātou = Struggle without end. Auckland, N.Z: Penguin.

Wikaira-Murray, J. (2012). Te Aka Project: Maori Student Experiences of the University of Otago Library [Unpublished report]. Dunedin, New Zealand: University of Otago Library. 


\section{Participant Information Sheet (Phase One: Planning)}

Project Title: Exploring a Kaupapa Māori-inspired approach to Teaching \&

Learning Information Research Skills in an academic Library

E ngā mana, E ngā reo.

Tēnei te mihi whānui atu ki a koutou katoa, ngā uri o ngā hau e whā.

\section{Who am I? / Ko wai au?}

My name is Alexander Ritchie, and I am the kairangahau $\mid$ researcher in this project. I am a Masters of Information Studies (MIS) student enrolled at the School of Information Management, Victoria University of Wellington I am also one of the staff at the University of Otago Science Library, where I work as a liaison librarian, and I am also a kaiawhina contact for Māori students within the Division of Sciences. For this project, I will be working alongside Jeanette Wikaira-Murray, who is the Kaituitui Rātonga Māori | Māori Services Portfolio Librarian at the University of Otago Library.

\section{What is the research about?}

This research is part of my Masters of Information studies, and its purpose is to investigate and try to improve a small part of the library services for Māori science students at university. Specifically, I want to better understand what sorts of library teaching and learning will best support Māori science students getting the information research skills they require to succeed at university.

How will the research happen?

The project involves three stages: the first, which you are being invited to participate in, will involve hui kōrerorero focus groups \& interviews about issues and challenges that Māori students face in the library classes; in the second the researcher will use those discussions to help design and facilitate an information skills class; finally, there will be hui kōrerorero $\mid$ focus groups after each of the information research skills classes where different aspects of the information skills class will be discussed and evaluated.

\section{Who can participate in the research?}

The first part involves University staff and senior students in Sciences at the University. The third part will involve Māori undergraduate students enrolled in Science courses at the University of Otago.

\section{What will I ask you to do?}


Should you agree to participate in part one of this project, you will be invited to participate in a hui kōrerorero $\mid$ focus group facilitated by me. The purpose of the hui is to talk through the challenges Māori students face when engaging with the University library, in order to help develop a library information research skills session tailored to Māori undergraduate students.

Each hui will last around an hour. A digital audio recording will be made of the kōrero in the hui, and I will take notes.

\section{What will I do with the information?}

The information will be used in an Information Studies research report for my Masters degree. It may be presented on at a conference, and published about in a scholarly journal. The findings will also be made available to the University of Otago library to support strategic decisions. If you choose to participate, you can choose to be sent a draft version of the study report, on which I welcome your comments and feedback. Any feedback you provide will be incorporated into the final report. You can also choose to be given a summary of findings of the study report. There will be a research dissemination hui following the completion of the project, and should you wish, you will be invited to participate in that.

\section{Your Rights.}

Taking part is voluntary. You do not have to take part. If you do agree to take part you are free to withdraw from the interview or hui at any time before 26 April 2013, without having to give a reason. You do not have to answer all the questions. If you decide to withdraw, any information or comments you contributed will be wiped from the record and not used in the research.

\section{Your confidentiality.}

No information which could personally identify you will be used or published. All information will be held in confidence, and stored securely accessible only by myself as principal researcher, and by my supervisor, Dr. Sydney Shep. All interview and hui kōrerorero data will be destroyed 2 years after the completion of the project.

Thank you in advance for your time and help. If you have any queries or wish to know more about the project, please contact me: ritchialex@myvuw.ac.nz, or by phone on 0211370977 ; my research collaborator, Jeanette Wikaira-Murray: jeanette.wikaira-murrav@otago.ac.nz or at work on 479-5387; or my supervisor, Dr Sydney Shep, at the School of Information Management, Victoria University of Wellington, P. O. Box 600, Wellington, 6140, phone 044635784.

Ngā mihi mahana

\section{Nā, Alexander Ritchie}




\section{Participant Information Sheet (Phase Three: Evaluation)}

Project Title: Exploring a Kaupapa Māori-inspired approach to Teaching \& Learning Information

Research Skills in an academic Library

E ngā mana, E ngā reo.

Tēnei te mihi whānui atu ki a koutou katoa, ngā uri o ngā hau e whā.

\section{Who am I? / Ko wai au.?}

My name is Alexander Ritchie, and I am the kairangahau | researcher in this project. I am a Masters of Information Studies (MIS) student enrolled at the School of Information Management, Victoria University of Wellington. I am also one of the staff at the University of Otago Science Library, where I work as a liaison librarian. I am a kaiawhina contact for Māori students within the Division of Sciences. For this project, I will be working alongside Jeanette Wikaira-Murray, who is the Kaituitui Rātonga Māori $\mid$ Māori Services Portfolio Librarian at the University of Otago Library.

\section{What is the research about?}

This research is part of my Masters of Information Studies, and its purpose is to investigate and try to improve a small part of the library services for Māori science students at University. Specifically, I want to better understand what sorts of library teaching and learning will best support Māori science students getting the information research skills they require to succeed at university.

\section{How will the research happen?}

The project involves three stages: the first involved hui kōrerorero $\mid$ focus groups and interviews about issues and challenges that Māori students face in the library classes; in the second those discussions were used to help design the information research skills class that you participated in; finally, there will be hui kōrerorero $\mid$ focus groups after each of the information research skills classes, where different aspects of the information skills class will be discussed and your opinion will be sought.

\section{Who can participate in the research.?}

The first part involved Māori staff and senior Māori students at the University. The third part will involve Māori undergraduate students enrolled in Science courses at the University of Otago. 


\section{What will we ask you to do?}

Should you agree to participate in this project, following your attendance at the library information research skills session, you will be invited to participate in a hui kōrerorero $\mid$ focus group with me and a Māori facilitator. The purpose of the hui is to get your responses about the library information research skills session, so that I can understand whether this is a worthwhile way to support the success of Māori students at Otago University.

Each hui will last around an hour, and in it you will be asked some questions about your experiences of the session. A digital audio recording will be made of the kōrero in the hui, and I will take notes.

\section{What will we do with the informa tion?}

The information will be used in an Information Studies research report for my Masters degree. It may be presented on at a conference, and published about in a scholarly journal. The findings will also be made available to the University of Otago library to support strategic decisions. If you choose to participate, you will be sent a draft version of the study findings, on which we welcome your comments and feedback. Any feedback you provide will be incorporated into the final report. There will be a research dissemination hui following the completion of the project, and you will be invited to that.

\section{Your Rights.}

Taking part is voluntary. You do not have to take part. If you do agree to take part you are free to withdraw from the interview or hui at any time before 10 May 2013, without having to give a reason. You do not have to answer all the questions. If you decide to withdraw, any information or comments you contributed will be wiped from the record and not used in the research.

\section{Your confidentiality.}

No information which could personally identify you will be used or published. All information will be held in confidence, and stored securely accessible only by myself as principal researcher, and by my supervisor, Dr. Sydney Shep. All interview and hui kōrerorero data will be destroyed 2 years after the completion of the project.

Thank you in advance for your time and help. If you have any queries or wish to know more about the project, please contact me: ritchialex@myvuw.ac.nz , or by phone at home on 021137 0977; my research collaborator, Jeanette Wikaira-Murray: jeanette.wikaira@otago.ac.nz or at work on 479-5387; or my supervisor, Dr Sydney Shep, at the School of Information Management, Victoria University of Wellington, P. O. Box 600, Wellington, 6140, phone 044635784.

Ngā mihi mahana

\section{Nā, Alexander Ritchie}




\section{Consent Form (Phase One: Planning)}

Project Title: Exploring a kaupapa Māori-inspired approach to teaching \& learning information research skills in an academic library

I have been given an explanation about this project, and understand what the research is about. All my questions have been answered to my satisfaction, and I understand that I can ask for further information at any point in the process.

I understand that my participation in the project is completely voluntary, and I am free to withdraw at any time before 26 April 2013 without giving any reasons and without any disadvantage. If I decide to withdraw, I understand that any information or comments I contributed will be wiped from the record and not used in the research.

I know that:

- any information or opinions I provide will be kept confidential to the researcher and his supervisor, and will be reported without my name attached, and in a way that means I can't be identified.

- I can choose to receive a draft version of the study report that I can comment on and make additional contribution. Any comments or feedback I provide will be incorporated into the final report. I can also choose to be given a summary of findings of the study report, and I will be invited a research dissemination hui on the University of Otago campus following the completion of the project.

- the results of the project may be published or used for a presentation at an academic conference, as well as being presented in the researcher's Masters project report.

- If I have any concerns, I can raise them with the researcher, his supervisor, or his collaborator, listed on the information sheet;

I wish to receive a copy of the draft project report to provide feedback on.

I wish to receive a summary of the project's findings.

I wish to be invited to a research dissemination hui following the completion of this project.

Signed:

Name of participant

Date: 


\section{Consent Form (Phase Three: Evaluation)}

Project Title: Exploring a kaupapa Māori-inspired approach to teaching \& learning information research skills in an academic library

I have been given an explanation about this project, and understand what the research is about. All my questions have been answered to my satisfaction, and I understand that I can ask for further information at any point in the process.

I understand that my participation in the project is completely voluntary, and I am free to withdraw at any time before 1 May 2013 without giving any reasons and without any disadvantage. If I decide to withdraw, I understand that any information or comments I contributed will be wiped from the record and not used in the research.

I know that:

- any information or opinions I provide will be kept confidential to the researcher and his supervisor, and will be reported without my name attached, and in a way that means I can't be identified.

- I can choose to receive a draft version of the study report that I can comment on and make additional contribution. Any comments or feedback I provide will be incorporated into the final report. I can also choose to be given a summary of findings of the study report, and I will be invited a research dissemination hui on the University of Otago campus following the completion of the project.

- the results of the project may be published or used for a presentation at an academic conference, as well as being presented in the researcher's Masters project report.

- If I have any concerns, I can raise them with the researcher, his supervisor, or his collaborator, listed on the information sheet;

I wish to receive a copy of the draft project report to provide feedback on.

I wish to receive a summary of the project's findings.

I wish to be invited to a research dissemination hui following the completion of this project.

Signed:

Name of participant

Date: 


\section{Appendix Two}

\section{Kaupapa MIori-inspired teaching \& learning approach to information research skills - Guide for Staff \& Senior Science Student Planning Hui Kōrerorero}

\section{Preliminaries}

Karakia - Tuwhera

Mihi whakatau - introduce the hui and myself

Purpose of Research: Masters Library Studies. Action research. Gather perspectives from you as Māori staff about Māori students in the library and the ways the library can best support their success at University. Particularly when it comes to library or information research skills classes. Introductions: Invite people to do a round of introductions. Then we'll have some kai, then get on with some more kōrero.

Karakia mo te kai

Kai

\section{Housekeeping}

Time limit

Confidentiality

Use of tape recorder and note taking

Interview consent forms

Explanation of the process

\section{Hui krrerorero}

Begin with brief overview of this hui kōrerorero

(The purpose is to gather ideas and feedback about what sorts of teaching and learning in the library work best for Māori students at Otago University).

Ensure everyone understands the process; questions to me are welcome at any time; posing further questions to the group are also welcome at any time.

\section{Introduction}

In your experience, what do you see as the key challenges for Māori students at Otago University accessing the Library?

\section{Main}

\section{Challenges/Barriers}

What do you hear from students are their main challenges in the library?

Needs

What do you see as the main needs for Māori students to get from the library?

Information Literacy

What does 'information literacy' or 'information research skills' mean to you?

\section{Teaching \& Learning}


As I am wanting to design a library session for undergraduate Māori students, what are some key things I need to pay attention to?

If I want to engage the students, what are some ways to do that in your experience?

Library sessions can feel formal or irrelevant, what would make it relevant and useful for the students?

\section{Narratives}

I have some ideas about using particular narratives - Maui/Tawhaki, and their quests for knowledge as a way of structuring a session. Do you have any thoughts on that?

\section{Ending}

Think about all that we have talked about in our hui. What are the most important things for me to take away with me?

Have I missed anything? Is there anything you would like to add or kōrero about further?

\section{Summary}

- Important issues \& common themes that came up in the discussion

- Discuss and agree on future feedback, and provision of draft findings for feedback to ensure reciprocity.

Wā whakamutunga

Mihi whakamutunga

Karakia whakamutunga 


\section{Appendix Three}

\section{Draft Class Outline : Library Information Skills session with $1^{\text {st }}$ year}

Māori students in Psychology

[20 mins]

Encounter \& Welcome

- open the space with karakia

- welcome and outline the session

- the library - starting out / whakapapa

- introductions $\mid$ mihi

- invite the students to identify one challenge they face in the library

- karakia kai \& kai

[20 mins]

Information Research Skills: getting an overview; finding a specific journal article; referencing that specific article

Looking for Māori sources. Weave the Tawhaki story into that

- exercise in pairs / small groups :

- searching the library \& web for sources on Maori Mental Health

- discussion about process of seeking the information you need.

- referencing that paper in APA - whakapapa

- feedback - what have we learnt

[10 mins $]$

Evaluation and Faresvell

Connecting back with the questions asked in the beginning about

- evaluation - how was the session

- Close the space with karakia 


\section{Appendix Four}

\section{Draft Evaluation approach for Library Information Skills session}

\section{Part One : In-class Evaluation}

At end of class, students will be asked three questions:

- What worked well today,

- what needs improvement,

- what should be changed.

They will be provided with stickies and big sheets of paper, and asked to write anonymous responses to the questions and stick them on the relevant sheet of paper.

\section{Part Two: Takeaway Questionnaire with Follow-up Email}

Following this, the students would be invited to provide further feedback via a google form They would be given a takeaway sheet inviting them to email me a few more thoughts on the process when they have a chance. One follow-up email reminder would be sent after two days. The questions would be:

1. If you were to tell one of your mates about the session today, what would you say to them? Awful, not that useful; take it or leave it; alright; awesome; Why?

2. Have you had difficulty accessing resources in the library? Yes/No; Why?

3. How often do you use the university library? - Everyday; couple of times a week; every week or so; the library? what's that

4. Should the library take a more kaupapa Māori approach to its support for Māori students? Yes/No; why? 
Alexander Ritchie - Word Count (excluding references) 14300 words 